\title{
GLOBAL SHOCKS, ECONOMIC GROWTH AND FINANCIAL CRISES: 120 YEARS OF NEW ZEALAND EXPERIENCE
}

\author{
Michael D. Bordo \\ David Hargreaves \\ Mizuho Kida \\ Working Paper 16027 \\ http://www.nber.org/papers/w16027
NATIONAL BUREAU OF ECONOMIC RESEARCH
1050 Massachusetts Avenue
Cambridge, MA 02138

May 2010

Some of this material is drawn from a lecture given by Michael Bordo during his Professorial Fellowship at the Reserve Bank of New Zealand in July 2009. We would like to thank Ozer Karagedikli, Gary Hawke, Chris Hunt, Chris Meissner, John Singleton and an anonymous referee for comments or advice; the usual disclaimer applies. The views expressed herein are those of the authors and do not necessarily reflect the views of the National Bureau of Economic Research.

NBER working papers are circulated for discussion and comment purposes. They have not been peerreviewed or been subject to the review by the NBER Board of Directors that accompanies official NBER publications.

(C) 2010 by Michael D. Bordo, David Hargreaves, and Mizuho Kida. All rights reserved. Short sections of text, not to exceed two paragraphs, may be quoted without explicit permission provided that full credit, including $\odot$ notice, is given to the source. 
Global shocks, economic growth and financial crises: 120 years of New Zealand experience Michael D. Bordo, David Hargreaves, and Mizuho Kida

NBER Working Paper No. 16027

May 2010

JEL No. G01

\begin{abstract}
We identify the timing of currency, banking crises and sudden stops in New Zealand from 1880 to 2008, and consider the extent to which empirical models can explain New Zealand's crisis history. We find that the cross country evidence on the determinants of crises fits New Zealand experience reasonably well. A number of the risk factors that correlate with crises internationally-such as domestic imbalances, external debt, and currency mismatches-were elevated for New Zealand when the country had more frequent crises and have improved in the recent (more stable) period. However, a time-series analysis of New Zealand growth over 120 years shows that global factors-such as the US growth rate and terms of trade-explain New Zealand growth fairly well, and that crisis dummy variables do not have significant additional explanatory power. This suggests that having sound institutions and policies may help avoid severe domestic crises, but will not be sufficient to avoid the domestic economic impact of the global business cycle.
\end{abstract}

Michael D. Bordo

Department of Economics

Rutgers University

New Jersey Hall

75 Hamilton Street

New Brunswick, NJ 08901

and NBER

bordo@econ.rutgers.edu

David Hargreaves

Reserve Bank of New Zealand

P.O. Box 2498, Wellington

New Zealand

RBNZ-INFO@rbnz.govt.nz
Mizuho Kida

Reserve Bank of New Zealand

P.O. Box 2498, Wellington

New Zealand

RBNZ-INFO2@rbnz.govt.nz 


\section{Introduction}

The shocks that New Zealand has recently faced in an environment of increasing globalisation of the world economy - integration in both goods and finance - have resonance to the first era of globalisation in the years 1880-1913. Globalisation has been associated with an increased incidence of financial crises including banking crises, currency crises, debt crises and sudden stops. ${ }^{2}$ Also along with globalisation business cycles have become increasingly synchronised across countries. They have become connected by common global shocks which are often financial in nature. In such an environment, a small open economy can be hit hard by financial crises leading to recessions. It can also be hit by real shocks that reduce its terms of trade and the volume of its exports. What factors can prevent global shocks from being so damaging?

In this paper, we look at the crisis history of the New Zealand economy, and consider how international cross-country evidence on the determinants of crises fits that history. This allows us to identify factors that appeared to increase New Zealand's susceptibility to certain sorts of crisis at certain periods, and we are able to use these results to make statements about how New Zealand's level of risk may have changed over recent years. We also see if changing crisis susceptibility has affected our macroeconomic dependence on the rest of the world.

In section two, we briefly review some of the extant cross-country literature on the incidence and determinants of various types of financial crises including banking, currency, debt crises and sudden stops. Based on this research we can isolate variables that can attenuate the impact of shocks. These include macro fundamentals like current account balance, low fiscal deficits, low money growth, low inflation, low debt to GDP ratios, and openness. They also include institutional variables like pegging to the gold standard before 1914, having an independent central bank that acts as a lender of last resort, having a Parliamentary government and especially, having low 'original sin' (foreign currency denominated debt), and low currency mismatches.

In section three, we look at the crisis history of New Zealand and consider

2 See Bordo et al (2001). Crisis incidence was relatively high during periods of globalisation, and also in the disruptive period of 'deglobalisation' between the two world wars. 
how it fared within the historical context of global financial crises. The New Zealand economy has been subject to frequent currency crises (from the 1930s until 1984) and sudden stops where unwillingness to invest in New Zealand forces the current account to rapidly reverse. It also had two relatively small but significant banking crises. However, overall the international comparison suggests that New Zealand did quite well in avoiding serious financial stress (particularly serious banking crises) as did several other countries like Canada and the Scandinavian countries which had sound institutions and policies.

In section four, we estimate the cross-country models of currency crisis and sudden stops reviewed in section two using an augmented dataset which includes New Zealand. In the existing literature, New Zealand is often not included in the estimation samples because of missing values in key variables. Based on the results from the estimation, we highlight factors which were important in mitigating or exacerbating crisis risk in the country. We find that in the first era of globalisation (1880-1913) New Zealand was less exposed to currency crises than the average country through having a larger trade surplus and more favourable terms of trade shocks, but was more exposed to sudden stops because of its high 'original sin'. In the second era of globalisation (after 1972), New Zealand was more exposed to currency crises than the average country despite its higher per capita income (which by itself tends to predict a lower risk of a crisis) because of its weak fundamentals. Improvements in these fundamentals since the mid 1990s appear to have reduced the risk of currency crises in New Zealand today from a decade ago.

In section five, we explore the impact on New Zealand growth of the financial crises as well as global variables such as major country growth or the terms of trade. We find that global variables are effective in explaining smoothed paths for New Zealand growth, with the specification surprisingly robust over the roughly 120 year period. Once the impact of key global variables is taken into account the financial crises in New Zealand appear to have little additional explanatory power for the country's medium-term growth paths. This may suggest that financial crises in New Zealand have mainly been an endogenous response to stress brought on by exogenous global forces rather than a significant independent source of variation in the New Zealand growth rate. 


\section{Review of cross-country literature on financial crises and their determinants}

\subsection{Banking and currency crises and sudden stops from 1880 to 1997}

Bordo et al (2001) identified currency crises, banking crises and twin crises for a panel of 21 countries (both advanced and emerging) from 1880 to 1997 and also for a larger panel of 56 countries from 1973 to 1997. Currency crises, defined as a market based attack on the exchange value of a currency, were identified using an 'exchange market pressure indicator' defined as a weighted average of changes in exchange rates, reserves and short-term interest rates, and alternatively, a survey of expert opinion. Banking crises defined as bank runs, significant bank failures, suspensions of convertibility and fiscal resolutions were based on World Bank dates for post 1971 and on historical narratives for earlier periods. Twin crises were defined as banking and currency crises in the same or consecutive years.

Other papers in the crisis literature have also looked at sovereign debt crises, and sudden stops. Because New Zealand has not experienced a sovereign debt crisis, we do not discuss that literature in this paper. A sudden stop is defined as an abrupt reduction in net capital inflows (or a relevant proxy), with some definitions also requiring that the reduction in capital inflow must be coincident with or precede a decline in real GDP. Sudden stops are fairly common in New Zealand economic history (see section 3).

Bordo et al (2001) and subsequent papers have developed stylised facts on crisis incidence including the following:

- Crises are reasonably frequent and appear to have gradually become more frequent in recent years, with crisis incidence in the Bordo et al (2001) dataset averaging around 12 percent of country years in the dataset since 1973.

- Typically crisis incidence is higher in emerging economies, with the period between the two world wars one exception.

- Crises are correlated with substantial periods of below trend economic growth that cumulate into significant implied output loss.

There is considerable historical evidence of contagion (or at least bunching across countries) of financial crises. This may reflect common fundamentals such as similar current account imbalances or similar balance sheet problems in the banking system. It also may reflect transmission of shocks between 
countries via the current and capital accounts. For example, figure 1 shows the countries affected by crises in the same year from the first openness period and the sample of countries in Bordo and Meissner (2006a). ${ }^{3}$

\section{Figure 1}

\section{Crisis dates in the first Globalisation period}

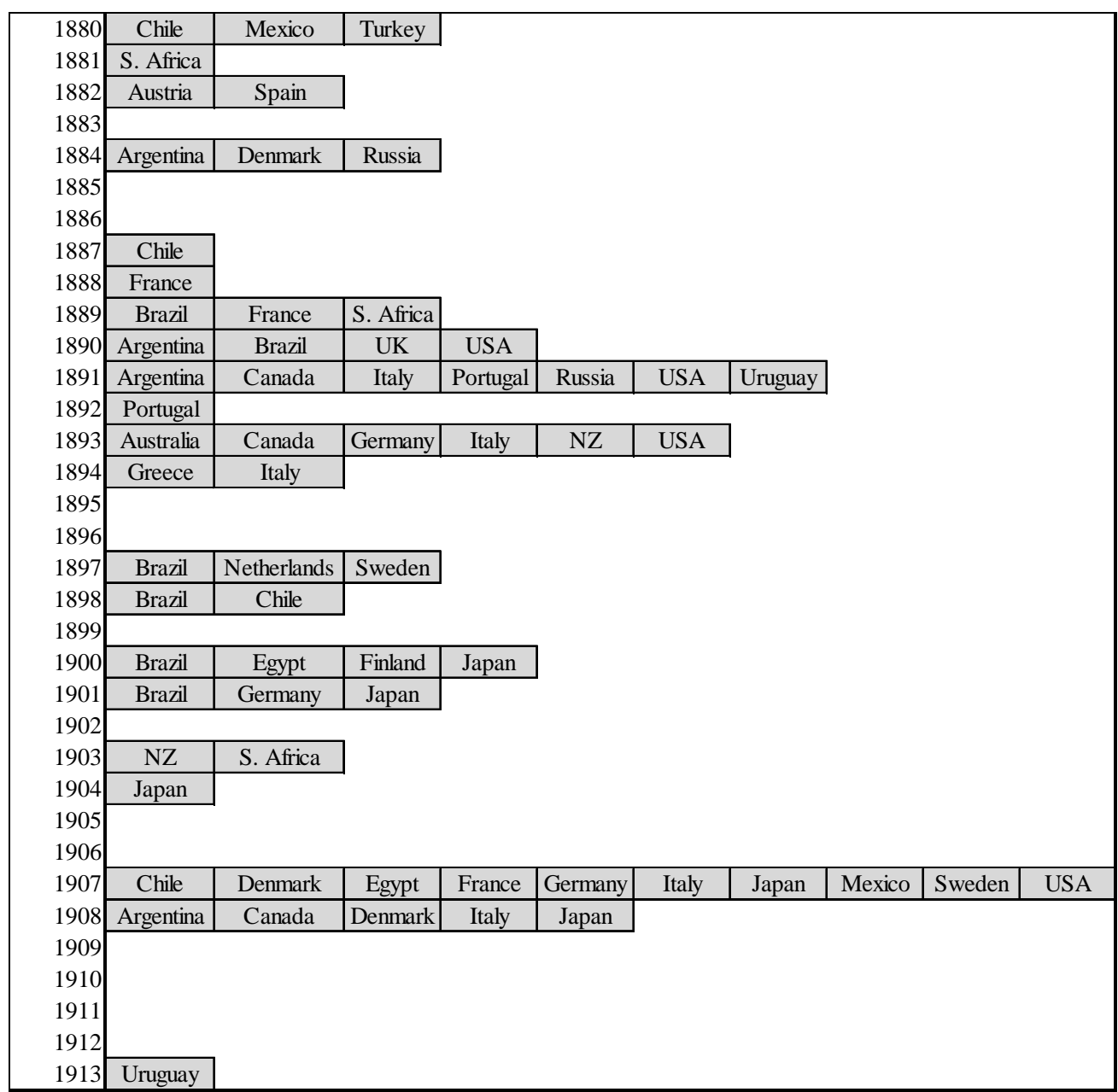

Source: Bordo and Meissner (2006a). Crises include currency, banking and debt crises.

\footnotetext{
${ }^{3}$ Also see Reinhart and Rogoff (2008) who have extended the data base of financial crises in Bordo et al (2001) to include many more countries and to include episodes back to 1800 and forward to 2008. The pattern echoes that of figure 1 but shows the recurrence of banking crises in the 1980s and 1990s and the return of a financial crisis today.
} 


\subsection{Determinants of Crises}

Bordo and Meissner (2009) outline theoretical reasons to expect foreign capital flows to increase susceptibility to financial crises and consider institutional variables that may alter that susceptibility. Where a period of buoyant capital inflows has coincided with a period of excessive optimism and sparked rising asset prices and leverage, economies become vulnerable to shifts in the willingness of creditors to roll over loans and supply further capital. It is harder for an asset price cycle to develop if capital inflows are not able to play a part (since the banking system's ability to expand its balance sheet to accommodate rising asset prices will be constrained). When capital inflows become less forthcoming, policy options for the country depend on factors like whether there is a lender of last resort; deep and liquid financial markets exist; the quality of private lending has been high; international borrowing has been in local currency; and the fiscal position is sound. These factors help generate credibility and confidence and provide room for the government and central bank to provide liquidity support to the financial system. If they are not present, the risk that a desire to withdraw capital becomes disorderly (leading to a sudden stop and potential currency and banking crises) is more significant.

The denomination of fiscal and private sector debt is often an important factor in increasing susceptibility to financial crises. The denomination of fiscal and private sector debt in foreign currency (called 'original sin' by Eichengreen and Hausmann, 1999) makes exchange rate depreciation expand the scale of debt relative to the domestic economy. Substantial foreign exchange reserves can mitigate this risk to a degree, but it has been a relevant part of a number of currency and financial crises (such as the 1990s Asian crises) and appears likely to afflict some countries today. A more robust solution is to borrow (directly or effectively after hedging contracts) in local currency, so that debt does not expand automatically as the currency falls. However there are relatively few countries that are able to do this to a significant degree.

Below we outline empirical evidence from a number of studies based on the Bordo et al (2001) dataset on the determinants of financial crises. The data provide information on crisis incidents and a wide-range of macroeconomic and institutional variables for over 40 countries between 1880 and 1997. The period is divided into four sub-periods: the gold standard era (1880-1913), the inter-war period (1919-1939), the Bretton Woods era (1945-1971), and the post-Bretton Woods era (1972-1997). The gold standard era and the post- 
Bretton Woods era are considered to be the periods of globalisation in both goods and services, and of frequent financial crises. Consequently, crisis studies tend to focus on these two periods. In section 4 we will look at how New Zealand compares to the sample of countries in crisis incidence and determinants during these two periods.

\section{Determinants of sudden stops}

Bordo, Cavallo and Meissner (2009) provide evidence on the determinants of sudden stops in the first era of globalisation 1880-1913, using a pooled probit methodology and a sample of 20 emerging countries. Their principal results are that countries which are more open, have lower levels of original sin and strong fundamentals (represented by high international reserves to notes ratios, lower ratios of debt to GDP, lower rates of money growth, lower current account deficits, and higher per capita GDP) have significantly lower probabilities of being hit by a sudden stop. They also find that a rise in the Bank of England's Bank rate significantly raises the probability of a sudden stop.

They then test for the growth effects of sudden stops. Their results, based on a treatment effects growth regression to deal with problems of endogeneity, are that sudden stops reduce growth by around 4 percent in the year a sudden stop occurs. Sudden stops that are accompanied by financial crises reduce growth an additional 3.6 percentage points.

\section{Determinants of currency crises}

Bordo and Meissner (2009) and Bordo, Meissner and Stuckler (2009) provide evidence on the determinants of currency crises using a pooled regression for 19 countries in the first era of globalisation (1880-1913) and for 45 countries in the second era of globalisation (1973-1997). For the first era of globalisation, they find that a large positive change in the current account to GDP ratio and low levels of reserves to notes are both associated with high probabilities of a currency crisis. This suggests that currency crises are driven by current account reversals and sudden stops. Other variables that lead to currency crises include high levels of original sin and a low foreign currency debt mismatch. For the second era of globalisation, Bordo and Meissner (2006) and Bordo, Meissner and Stuckler (2009) find that high current account deficits increase the probability of a currency crisis, as do rapid money growth and rising foreign interest rates. They also show that high original sin, unless offset by a low mismatch, leads to a greater likelihood of a currency crisis.

\section{Determinants of banking crises}

Bordo and Meissner (2006a, 2006b) provide evidence on the determinants of banking crises using a pooled probit for 30 countries from 1880-1913 and 
over 40 countries between 1972 and 1997. In the first globalisation era, countries with weaker fundamentals and financial development tended to be more crises prone. Typically these countries had moderate original sin. They also find that the risk of a crisis is offset by a low mismatch, defined as international reserves less outstanding hard currency debt divided by exports.

For the second era of globalisation, Bordo and Meissner find that original sin and a high mismatch is associated with a greater chance of a financial crisis but that countries with higher levels of per capita income can offset this. Other factors leading to a banking crisis include rapid money growth, high current account deficits and high foreign interest rates.

The empirical evidence surveyed above suggests that debtor countries with sound fundamentals and institutions could avoid financial crises. A key determinant of crises in both eras of globalisation was the exposure to foreign currency debt. However, this could be mitigated by other institutional factors. Countries like the British Dominions, Sweden and Denmark and the US in the first era exhibited low risk despite high ratios of foreign currency debt to total debt, reflecting their ability to offset their exposures with high export receipts in foreign currency or by having large international reserves. It also reflected the fact that they had 'country trust' which Caballero, Cowan and Kearns (2006) describe as being associated with sound institutions, the rule of law and stable political systems.

\section{History of Financial Crises in New Zealand}

New Zealand has been exposed through its short history to both financial crises and real shocks. However, its experience with financial crises has been relatively benign. New Zealand has not experienced a sovereign debt crisis, and its two episodes of banking crisis appear relatively mild compared to some international experience. ${ }^{4}$ With the exception of a number of currency crises in the mid twentieth century its mild crisis experience may only have been surpassed by Canada. In this section, we assemble historical data to analyse crisis incidence for New Zealand using historical narratives and the quantitative methodologies from the literature reviewed in section 2.

Table 1 contains a chronology of New Zealand's financial crisis experience

\footnotetext{
${ }^{4}$ Reinhart and Rogoff (2008) distinguish the "big five” post-war developed country banking crises and show they were coincident with severe economic downturns in those countries, much worse than milder banking crises in their dataset including New Zealand's 1987 crisis.
} 
summarising the crisis dates we use based on the balance of evidence analysed. The reasoning follows, with further technical and data details available in the appendix. While the precise start and end dates of each crisis are no doubt open to debate, we think the dates chosen form a reasonable basis for the empirical work in the remainder of the paper.

\section{Table 1}

\section{Crisis dates for New Zealand}

\begin{tabular}{|l|l|l|}
\hline Banking & Currency & Sudden Stops \\
\hline & & $\mathbf{1 8 8 6 - 1 8 9 0}$ \\
\hline $1890-1895$ & & $\mathbf{1 8 9 6 , 9 8 - 9 9}$ \\
\hline & & $\mathbf{1 9 0 9 , 1 4 - 1 5}, 19$ \\
\hline & & $\mathbf{1 9 3 1 - 3 3}$ \\
\hline & 1931,33 & \\
\hline & 1938 & $1940,1944-46$ \\
\hline & & 1953,59 \\
\hline & 1967 & $1972-73$ \\
\hline & $1974-75,79-80$ & $\mathbf{1 9 7 6 - 7 8}$ \\
\hline & 1984 & $1987-88,91$ \\
\hline & & $1998-99$ \\
\hline
\end{tabular}

Note: Sudden stops are listed in bold if they were coincident with declining real GDP on an annual basis. These are described in Bordo et al (2001) as SS1. The other sudden stops are referred to below as SS2.

Hunt (2009) looks at the New Zealand historical record and identifies two banking crises (1890-95 and 1987-1990). The first crisis (1890-95) began with problems in the late 1880s and ended with a government rescue of the Bank of New Zealand (BNZ) in 1895. The crisis was caused by the collapse of a land boom in the mid- 1880s. The boom in pastoral land was in turn triggered by massive government investment in infrastructure in the $1870 \mathrm{~s}$ and favourable wool prices. The boom ended as global commodity prices declined and credit provision tightened, as the decline in export prices reduced land prices below those capitalized in mortgages and bank credit. 
This put pressure on the BNZ which had been a key lender. The pressure on the BNZ and other New Zealand financial institutions was heightened by global events: a sudden stop prompted by the Bank of England raising the Bank rate in the late 1880s, the Baring crisis of 1890 in Argentina and London, and a massive banking panic in Australia in 1893. The deeper underlying cause for all of these crises was a deepening gold deflation reflecting a global excess demand for gold in a world on the gold standard. Deflationary pressure only ended following gold discoveries in Alaska and South Africa in the 1890s. Fearing the effects on the real economy of insolvency the BNZ was recapitalized by the government in July 1895. The cost of the bailout is estimated to be 1.6 percent of GDP. This was very mild compared to Australia's crisis which cost well in excess of 10 percent of GDP.

The second banking crisis (1987 to 1990) also involved the BNZ which at the time was predominately government owned. The crisis started with a bank-financed property boom following deregulation of the financial system in 1984. The bust followed the October 1987 Wall Street and local equity market crash, which caused a commercial property bust, the failure of several non bank financial institutions and substantial losses for the BNZ. The BNZ was recapitalised in 1990 at a cost of approximately 1 percent of GDP.

We identify currency crises based on an exchange market pressure index supplemented with historical narrative. New Zealand was adjudged to have experienced seven currency crises. All of them occurred during pegged exchange rate regimes. The first three occurred during the Great Depression of the 1930s. A crisis in 1931, the worst year in the global slump, reflected pressure on the foreign exchange holdings of the trading banks. It led to a $10 \%$ depreciation of the NZ pound relative to sterling (Quigley 1992) and the temporary imposition of exchange controls. In 1933, still in the face of contractionary pressure, the NZ pound was devalued by 25 percent against sterling. Depletion of the banking system's foreign exchange reserves prompted another crisis in 1938. This led to the institution of a strict exchange control and import licensing regime which lasted until the 1980s.

Another series of crises occurred during the Bretton Woods regime after 1944. New Zealand didn't join the IMF until 1961 and kept both capital and import controls throughout the regime. Quigley (1992) describes a series of crises in the 1950s, but these did not lead to exchange rate depreciation or rising interest rates (instead typically being mitigated via intensified import controls) so do not meet our definition of a currency crisis.

The fourth crisis followed the collapse in the wool market in 1966. Wool prices declined by around 20\% in each of 1967 and 1968 (Reddell and 
Sleeman 2008). This caused deterioration in the current account and a depletion of New Zealand's reserves. In response the government borrowed from the IMF, tightened import controls and then, following Britain's devaluation of sterling in November, New Zealand devalued its currency by about 20 percent.

The fifth and sixth crises followed the oil price shock of 1973 which led to a substantial decline in New Zealand's terms of trade, a serious recession and severe pressure on the balance of payments. The NZ dollar was devalued in 1975 and again in 1976. The second oil price shock in 1979 had similar but less severe effects than the first shock. In response the NZ dollar was devalued by 5 percent in mid 1979 and the country adopted a crawling peg which was abandoned in 1982.

The final currency crisis we record was in 1984. The NZ dollar was devalued by 20 percent following a serious currency crisis during the election campaign. This was quickly followed by deregulation of the financial sector and the elimination of exchange and capital controls.

We identify sudden stops using two measures: SS1 considers a country as having a sudden stop during a given year if there is an annual drop in net capital inflows of at least two standard deviations below the mean of the year to year changes for the period, and /or it is the first year of a drop in net capital inflow that exceeds 3 percent of nominal GDP over a period shorter than four years, and if there is a drop in real GDP (of any magnitude) during that year or the following year. In Table 1 we mark SS1s in bold; SS2 is a broader indicator that does not need to be coincident with declining output.

As can be seen from Table 1, the incidence of several years of sudden stops in the 1880s preceded the banking crisis of 1890-95. Sudden stops also occurred at the start and end of World War I and preceded the currency crises during the Great Depression. In the post-war period they preceded the currency crises of 1974-75 and 1979 but followed the banking crisis of 1990 possibly reflecting the recession of 1991-92. Sudden stops (SS2) occurred during the Asian/Russian crisis but did not lead to a crisis in New Zealand. 


\section{Analysis of cross-country determinants of financial crises and implications for New Zealand}

Following Bordo and Meissner (2005a, 2005b, and 2007), we examine determinants of currency crises and sudden stops using their cross-country dataset but augmented with New Zealand data. In the previous studies, New Zealand drops out of the estimation sample because of missing values in key variables.

As in the previous studies based on the Bordo et al (2001) dataset, we focus on the two periods of globalisation (1880-1913 and 1972-1997) and estimate the models of currency crises and sudden stops using pooled regressions with robust standard errors clustered at the country level. A pooled regression is a common strategy to deal with highly unbalanced panel datasets like this one. Many of the countries in the sample have limited timeseries observations, so a panel regression would severely limit the number of countries remaining in the estimation sample. ${ }^{5}$ A pooled regression involves pooling observations across country- and time-dimensions such that a unit of observation becomes a country-year, not a country. To allow for the fact that same countries are repeatedly observed in the sample, we use robust standard errors which allow individual country's errors to be correlated over time. Table A1 and A2 in the appendix report countries in the estimation sample and the frequency of crises each had during the two periods of globalisation.

Tables 2-4 report our results which highlight the factors associated with currency crises and sudden stops for a broad group of countries (including New Zealand). In each table, column (1) is our benchmark specification with all of the key explanatory variables. Overall, the findings of the cross country regressions are similar to those reported in Bordo and Meissner (2005a, 2005b, and 2007). Many variables are statistically significant, suggesting that countries' policies exerted an important influence on the risk of currency crises and sudden stops.

\subsection{The first era of globalisation, $\mathbf{1 8 8 0 - 1 9 1 3}$}

In the first era of globalisation New Zealand had no currency crises but faced frequent sudden stops. Our cross-country regression results suggest that

\footnotetext{
${ }^{5}$ The New Zealand data we have added has nearly complete time series observations for both periods of globalisation.
} 
countries that had frequent currency crisis in this period often had large trade deficits, negative terms of trade shocks, and high mismatches (table 2). Original sin by itself was not significantly related to more currency crises (column $1-3$ ). Countries that had a pegged exchange rate (which would often have been a commitment to the gold standard) experienced more currency crises during this period. The latter may reflect the fact that a peg is more likely to be defended (leading to declining reserves and rising interest rates, which are used as evidence of a currency crisis) and will be more subject to speculative attack than a clean float. However, the evidence that pegs are more crisis prone may be the result of selection bias, as some countries which had been too weak to remain formally pegged were forced to float in this era.

Our cross-country regression results also showed that countries that experienced frequent sudden stops in this period tended to have high original sin, large trade deficits, and were relatively closed to international trade (table 3). A higher original sin was an independently significant factor for sudden stops during this period, unlike for currency crises. The composition of debt captured by original sin (the share of hard-currency debt in total debt) seem to matter for sudden stops whether we control for the level effect (foreign currency debt relative to GDP or total debt relative to GDP, the latter not shown). Countries with relatively high per capita incomes, which could be a proxy for a better set of institutions, more developed financial systems, and/ or better management of debt, tended to have fewer crises.

Drawing implications for New Zealand, figure 2 plots the estimated probability of a crisis in New Zealand over the first period of globalisation. Predicted risk for New Zealand was elevated in the late 1880s due to a combination of a large trade deficit and negative terms of trade shocks. While terms of trade remained volatile throughout, a turnaround in the trade balance to a strong surplus in subsequent years contributed to lower predicted risks for the rest of the period. Figure 3 plots determinants of predicted risk of a currency crisis in New Zealand vis-à-vis average predicted risk for the sample. ${ }^{6}$ The results suggest that New Zealand managed to avoid currency crises by maintaining on average a higher trade surplus and lower debt on average, which offset its relative vulnerability from having a larger mismatch, a pegged exchange rate, and lower gold reserves. Overall New Zealand's average predicted risk was slightly higher than the average predicted risk for the sample for the period.

${ }^{6}$ Average predicted risk in the sample is the estimated probability of currency crises when all explanatory variables are held at the sample averages. 
Table 2

Determinants of currency crises, 1880-1913

\begin{tabular}{|c|c|c|c|c|c|c|c|c|}
\hline & (1) & & (2) & & (3) & & (4) & \\
\hline \multirow{2}{*}{ Original Sin } & -0.052 & & -0.030 & & -0.019 & & & \\
\hline & $(0.044)$ & & $(0.046)$ & & $(0.041)$ & & & \\
\hline \multirow[t]{2}{*}{ Original $\operatorname{Sin} \wedge 2$} & 0.034 & & 0.011 & & 0.002 & & & \\
\hline & $(0.046)$ & & $(0.048)$ & & $(0.042)$ & & & \\
\hline \multirow[t]{2}{*}{ Mismatch } & 0.003 & $* * *$ & 0.003 & & 0.002 & & & \\
\hline & $(0.001)$ & & $(0.002)$ & & $(0.002)$ & & & \\
\hline \multirow[t]{2}{*}{ Debt/revenue } & -0.002 & * & -0.002 & & -0.001 & & -0.002 & \\
\hline & $(0.001)$ & & $(0.002)$ & & $(0.001)$ & & $(0.002)$ & \\
\hline \multirow[t]{2}{*}{ Growth of terms of trade } & -0.916 & $* * *$ & -0.880 & $* * *$ & -0.905 & $* * *$ & -0.917 & $* * *$ \\
\hline & $(0.236)$ & & $(0.274)$ & & $(0.288)$ & & $(0.305)$ & \\
\hline Trade balance/ GDP & $\begin{array}{c}-0.004 \\
(0.002)\end{array}$ & $* *$ & $\begin{array}{l}-0.004 \\
(0.002)\end{array}$ & $* *$ & $\begin{array}{l}-0.004 \\
(0.002)\end{array}$ & $* * *$ & $\begin{array}{l}-0.004 \\
(0.002)\end{array}$ & $* *$ \\
\hline Long-term interest rates & $\begin{array}{r}-0.007 \\
(0.005)\end{array}$ & & $\begin{array}{l}-0.001 \\
(0.004)\end{array}$ & & $\begin{array}{r}0.000 \\
(0.004)\end{array}$ & & $\begin{array}{r}-0.001 \\
(0.005)\end{array}$ & \\
\hline Consol interest rate & $\begin{array}{l}-0.019 \\
(0.017)\end{array}$ & & & & & & & \\
\hline Gold coverage ratio & $\begin{array}{r}-0.033 \\
(0.025)\end{array}$ & & $\begin{array}{r}-0.046 \\
(0.032)\end{array}$ & & $\begin{array}{c}-0.052 \\
(0.030)\end{array}$ & $*$ & $\begin{array}{r}-0.025 \\
(0.030)\end{array}$ & \\
\hline Pegged exchange rate & $\begin{array}{r}0.021 \\
(0.007)\end{array}$ & $* * *$ & $\begin{array}{r}0.033 \\
(0.012)\end{array}$ & $* * *$ & $\begin{array}{r}0.039 \\
(0.011)\end{array}$ & $* * *$ & $\begin{array}{r}0.031 \\
(0.010)\end{array}$ & $* * *$ \\
\hline Inflation & $\begin{array}{r}0.000 \\
(0.001)\end{array}$ & & & & & & & \\
\hline Ln(GDP per capita) & $\begin{array}{c}-0.008 \\
(0.007)\end{array}$ & & $\begin{array}{c}-0.007 \\
(0.008)\end{array}$ & & $\begin{array}{r}-0.007 \\
(0.009)\end{array}$ & & $\begin{array}{r}-0.010 \\
(0.009)\end{array}$ & \\
\hline Banking crisis & $\begin{array}{r}0.062 \\
(0.062)\end{array}$ & & $\begin{array}{r}0.064 \\
(0.061)\end{array}$ & & $\begin{array}{r}0.065 \\
(0.063)\end{array}$ & & $\begin{array}{r}0.061 \\
(0.061)\end{array}$ & \\
\hline Observations & 433 & & 434 & & 434 & & 434 & \\
\hline Observed Risk & 0.032 & & 0.035 & & 0.035 & & 0.035 & \\
\hline Predicted Risk (at x-bar) & 0.016 & & 0.019 & & 0.020 & & 0.020 & \\
\hline Percent of Correct Positive $†$ & 71.4 & & 73.3 & & 73.3 & & 80.0 & \\
\hline Percent of Correct Negative $†$ & 69.0 & & 71.1 & & 72.8 & & 70.2 & \\
\hline Pseudo $\mathrm{R}^{2}$ & 0.171 & & 0.160 & & 0.155 & & 0.1535 & \\
\hline
\end{tabular}

Note: Dependent variable is a binary indicator for a currency crisis. Explanatory variables are in one-period lag ( $\mathrm{t}-1$ ) unless otherwise indicated. Reported coefficients are marginal effects of variables on the probability of a currency crisis. Robust clustered standard errors are in parentheses. * significant at $10 \%$; ** significant at $5 \%$; *** significant at $1 \%$. † Cutoff $=$ observed risk in the data. 


\section{Table 3}

\section{Determinants of sudden stops, 1880-1913}

\begin{tabular}{|c|c|c|c|c|c|c|c|c|}
\hline & $(1)$ & & $(2)$ & & (3) & & $(4)$ & \\
\hline \multicolumn{9}{|l|}{ Original Sin (Hard Currency } \\
\hline Debt to Total Debt) & $\begin{array}{r}0.066 \\
(0.017)\end{array}$ & $* * *$ & & & $\begin{array}{r}0.066 \\
(0.017)\end{array}$ & $* * *$ & $\begin{array}{r}0.068 \\
(0.014)\end{array}$ & $* * *$ \\
\hline Hard currency debt to GDP & & & $\begin{array}{r}0.060 \\
(0.017)\end{array}$ & $* * *$ & & & & \\
\hline Trade Balance to GDP & $\begin{array}{r}-0.278 \\
(0.108)\end{array}$ & $* * *$ & $\begin{array}{r}-0.470 \\
(0.140)\end{array}$ & $* * *$ & $\begin{array}{r}-0.245 \\
(0.089)\end{array}$ & $* * *$ & & \\
\hline Trade Openness & $\begin{array}{c}-0.039 \\
(0.033)\end{array}$ & & $\begin{array}{c}-0.057 \\
(0.025)\end{array}$ & $* *$ & $\begin{array}{r}-0.051 \\
(0.029)\end{array}$ & $*$ & $\begin{array}{r}-0.050 \\
(0.027)\end{array}$ & $*$ \\
\hline UK Consol rate & $\begin{array}{r}-0.038 \\
(0.031)\end{array}$ & & $\begin{array}{r}-0.032 \\
(0.032)\end{array}$ & & & & & \\
\hline Growth of money & $\begin{array}{r}-0.037 \\
(0.054)\end{array}$ & & $\begin{array}{r}-0.021 \\
(0.064)\end{array}$ & & & & & \\
\hline Gold coverage ratio & $\begin{array}{r}-0.055 \\
(0.019)\end{array}$ & ** & $\begin{array}{r}-0.054 \\
(0.016)\end{array}$ & $* * *$ & $\begin{array}{r}-0.050 \\
(0.017)\end{array}$ & $* *$ & $\begin{array}{r}-0.034 \\
(0.015)\end{array}$ & $* *$ \\
\hline Ln(GDP per capita) & $\begin{array}{r}-0.008 \\
(0.006)\end{array}$ & & $\begin{array}{r}0.012 \\
(0.012)\end{array}$ & & $\begin{array}{r}-0.01 \\
(0.005)\end{array}$ & $* *$ & $\begin{array}{r}-0.016 \\
(0.005)\end{array}$ & $* * *$ \\
\hline Observations & 448 & & 445 & & 473 & & 473 & \\
\hline Observed Risk & 0.040 & & 0.040 & & 0.038 & & 0.038 & \\
\hline Predicted Risk (at x-bar) & 0.026 & & 0.029 & & 0.025 & & 0.025 & \\
\hline Percent of Correct Positive $†$ & 72.2 & & 72.2 & & 72.2 & & 77.8 & \\
\hline Percent of Correct Negative $†$ & 66.3 & & 71.0 & & 63.3 & & 63.3 & \\
\hline Pseudo $\mathrm{R}^{2}$ & 0.109 & & 0.103 & & 0.102 & & 0.085 & \\
\hline
\end{tabular}

Note: Dependent variable is a binary indicator for sudden stops (SS1). Explanatory variables are in one-period lag (t-1) unless otherwise indicated. Reported coefficients are marginal effects of variables on the probability of a sudden stop. Robust clustered standard errors in parentheses. *significant at $10 \%$; ** significant at $5 \%$; *** significant at $1 \%$. $†$ Cut-off $=$ observed risk in the data. 


\section{Figure 2}

\section{Predicted risk of a currency crisis for New Zealand, 1880-1913}

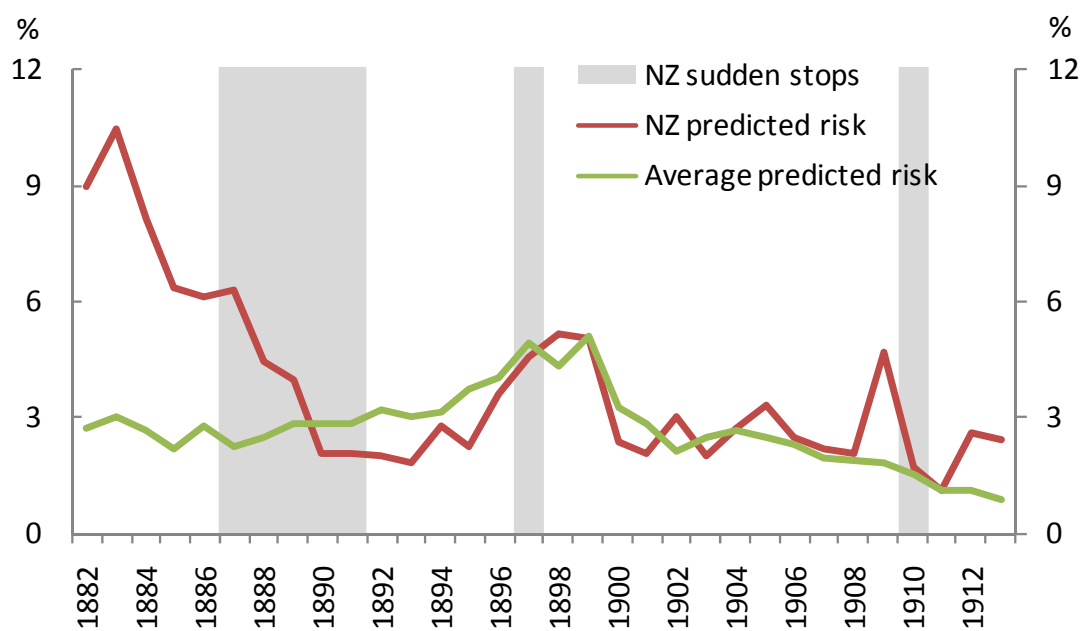

Note: * New Zealand did not have a currency crisis for this period.

\section{Figure 3}

Differences in predicted risk of a currency crisis for New Zealand vis-à-vis the average country (1880-1913 averages)

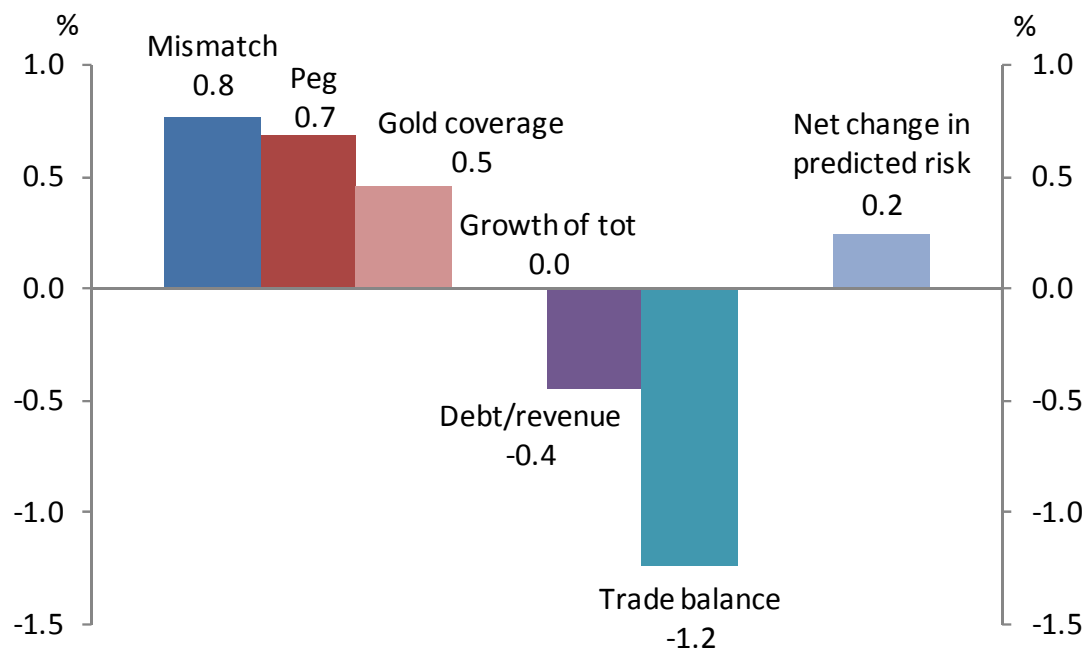

Note: The figure shows differences in predicted risk of a sudden stop for New Zealand vis-à-vis the average country in the sample. Each bar represents a marginal contribution of a significant variable in the model (reported in Table 2, column 1) to the difference in predicted probabilities between New Zealand and the average country in the sample. The marginal contribution of each of the variable is calculated by multiplying the estimated coefficient of the variable to the difference in the average values of the variable for this 
period between New Zealand and the average country in the sample. For example, New Zealand had a higher mismatch than the average country for the period, which the model estimates (other things being equal) would have added 0.8 percentage points to the predicted risk vis-à-vis the baseline (average country’s) probability.

Figure 4 and 5 repeat the exercise for sudden stops in 1880-1913, a period in which New Zealand had three sudden stops. Shaded regions in Figure 4 represent the actual years of crises. The model seems to predict well the periods of relative vulnerability of New Zealand to a sudden stop. Predicted risk for New Zealand tended to be higher in years preceding the actual years of crises. Figure 5 suggests that New Zealand's relative vulnerability to sudden stops in this period could be related to its higher level of original sin and to a lesser extent lower gold reserves than average. These effects offset vulnerability reductions from New Zealand's trade surpluses and relatively high openness. Overall, the predicted risk for New Zealand of a sudden stop was 1 percentage points higher than the average predicted risk for the sample.

\section{Figure 4}

\section{Predicted risk of a sudden stop for New Zealand, 1880-1913}

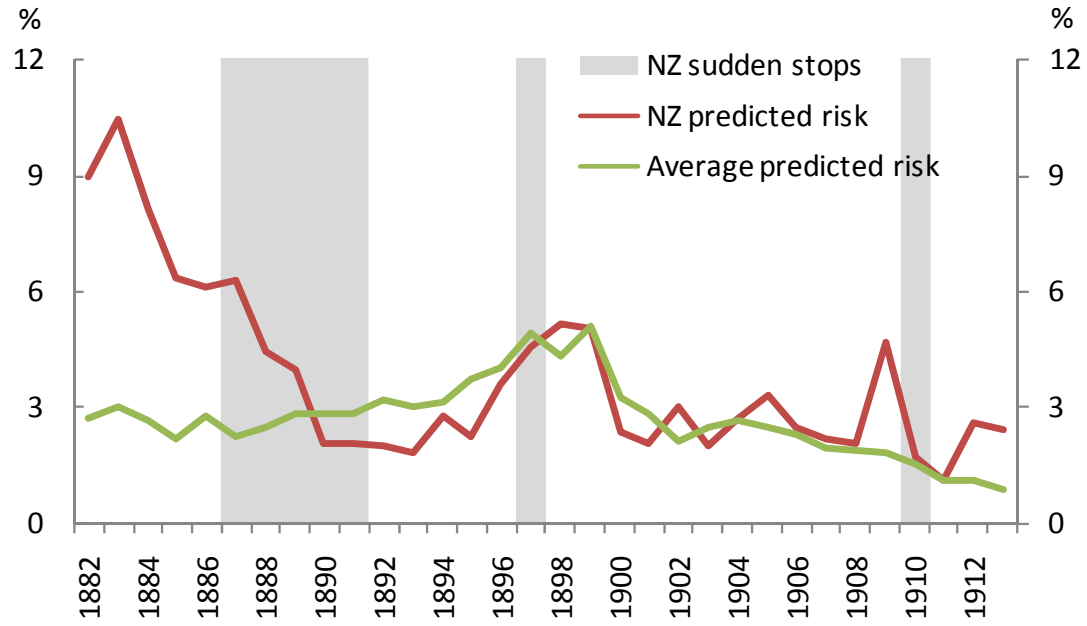




\section{Figure 5}

\section{Differences in predicted risk of a sudden stop for New Zealand vis- à-vis the average country (1880-1913 averages)}

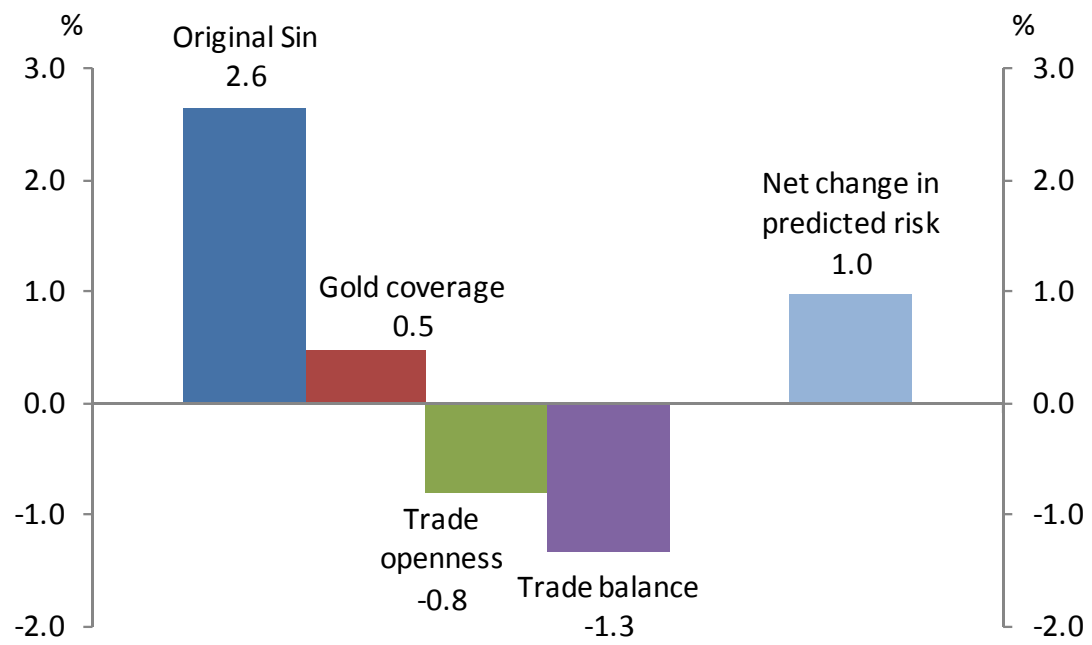

Note: The figure shows differences in predicted risk of a sudden stop for New Zealand vis-à-vis the average country in the sample. Each bar represents a marginal contribution of a significant variable in the model (reported in Table 3, column 1) to the difference in predicted probabilities. The marginal contribution of each of the variable is calculated by multiplying the estimated coefficient of the variable to the difference in the average values of the variable for this period between New Zealand and the average country in the sample. For example, New Zealand had a higher original sin than the average country for the period, which the model estimates (other things being equal) would have added 2.6 percentage points to the predicted risk vis-à-vis the baseline (average country's) probability.

\subsection{The second era of globalisation, 1972-1997}

In the second era of globalisation, New Zealand had more frequent currency crises but fewer sudden stops - the opposite of what it experienced in the first era of globalisation (table 1 and table A2). The cross-country results show that countries that had frequent currency crises in this period tended to have high original sin with mismatch, high overall levels of debt, high interest rates, a pegged exchange rate, and low international reserves (table 4). 


\section{Table 4}

\section{Determinants of currency crises, 1972-1997}

\begin{tabular}{|c|c|c|c|c|c|c|}
\hline & $(1)$ & & $(2)$ & & $(3)$ & \\
\hline \multirow[t]{2}{*}{ Original Sin } & 0.004 & * & 0.004 & $* *$ & & \\
\hline & $(0.002)$ & & $(0.002)$ & & & \\
\hline \multirow[t]{2}{*}{ Original $\operatorname{Sin} \wedge 2$} & $-3.0 \mathrm{E}-05$ & & $-2.6 \mathrm{E}-05$ & & & \\
\hline & $(2.3 \mathrm{E}-05)$ & & $(1.7 \mathrm{E}-05)$ & & & \\
\hline \multirow[t]{2}{*}{ Mismatch } & 0.029 & * & & & 0.006 & \\
\hline & $(0.016)$ & & & & $(0.021)$ & \\
\hline \multirow[t]{2}{*}{ Debt/output } & 8.3E-04 & $* *$ & 0.001 & $* * *$ & 2.5E-04 & \\
\hline & (3.4E-04) & & $(3.3 \mathrm{E}-04)$ & & $(5.9 \mathrm{E}-04)$ & \\
\hline \multirow[t]{2}{*}{ Growth of terms of trade } & 0.001 & & 4.7E-04 & & 0.001 & \\
\hline & $(0.001)$ & & $(1.0 \mathrm{E}-03)$ & & $(0.001)$ & \\
\hline \multirow[t]{2}{*}{ Trade balance/ GDP } & -0.003 & & -0.003 & & -0.003 & \\
\hline & $(0.003)$ & & $(0.002)$ & & $(0.004)$ & \\
\hline \multirow[t]{2}{*}{ Long-term interest rates } & 0.013 & * & 0.012 & * & 0.020 & $* * *$ \\
\hline & $(0.008)$ & & $(0.007)$ & & $(0.008)$ & \\
\hline \multirow[t]{2}{*}{ G7 av. Long-term interest rate } & 0.005 & & 0.005 & & -0.002 & \\
\hline & $(0.009)$ & & $(0.009)$ & & $(0.009)$ & \\
\hline \multirow[t]{2}{*}{ Pegged exchange rate } & 0.081 & $* *$ & 0.070 & $*$ & 0.023 & \\
\hline & $(0.046)$ & & $(0.044)$ & & $(0.045)$ & \\
\hline \multirow[t]{2}{*}{ Inflation } & 2.9E-04 & $* * *$ & 4.1E-04 & $* * *$ & $4.1 \mathrm{E}-04$ & $* * *$ \\
\hline & $(6.1 \mathrm{E}-05)$ & & $(1.2 \mathrm{E}-04)$ & & $(1.3 \mathrm{E}-04)$ & \\
\hline \multirow[t]{2}{*}{ Reserves/ M2 } & -0.164 & $* * *$ & -0.182 & $* * *$ & -0.101 & $* * *$ \\
\hline & $(0.055)$ & & $(0.045)$ & & $(0.050)$ & \\
\hline \multirow[t]{2}{*}{ Ln(GDP per capita) } & -0.019 & & -0.029 & * & -0.046 & $* * *$ \\
\hline & $(0.019)$ & & $(0.016)$ & & $(0.023)$ & \\
\hline \multirow[t]{2}{*}{ Banking crisis } & 0.028 & & 0.042 & & 0.019 & \\
\hline & $(0.044)$ & & $(0.041)$ & & $(0.040)$ & \\
\hline Observations & 389 & & 407 & & 452 & \\
\hline Observed Risk & 0.139 & & 0.135 & & 0.135 & \\
\hline Predicted Risk (at x-bar) & 0.095 & & 0.093 & & 0.114 & \\
\hline Percent of Correct Positive $†$ & 70.4 & & 74.5 & & 68.9 & \\
\hline Percent of Correct Negative $\dagger$ & 68.1 & & 65.1 & & 61.6 & \\
\hline Pseudo $\mathrm{R}^{2}$ & 0.156 & & 0.147 & & 0.083 & \\
\hline
\end{tabular}

Note: Dependent variable is a binary indicator for sudden stops (SS1). Explanatory variables are in one-period lag ( $\mathrm{t}-1$ ) unless otherwise indicated. Reported coefficients are marginal effects of variables on the probability of a sudden stop. Robust clustered standard errors in parentheses. *significant at $10 \%$; ** significant at $5 \%$; *** significant at $1 \%$. $†$ Cut-off $=$ observed risk in the data. 
Countries with relatively low per capita income (a proxy for'weak institutions') also suffered more crises. ${ }^{7}$

Figure 6 and 7 show predicted risk of a currency crisis in New Zealand relative to average for 1972-1997. Figure 6 shows that predicted risk for New Zealand was higher than for the average country in the sample throughout the period but especially between the mid 1970s and the mid 1980s when the country actually suffered frequent currency crises. Figure 7 suggests that New Zealand's vulnerability to currency crises over the period is related to its weak fundamentals in most relevant areas other than per capita income. It had higher original sin, higher debt relative to output, higher interest rates, and lower international reserves. The net predicted risk was nearly 9 percentage points higher than the average in the sample, although there were other countries in the sample (predominately developing countries) that suffered more crises and had higher predicted risk.

\section{Figure 6}

\section{Predicted risk of a currency crises for New Zealand, 1972-1997}

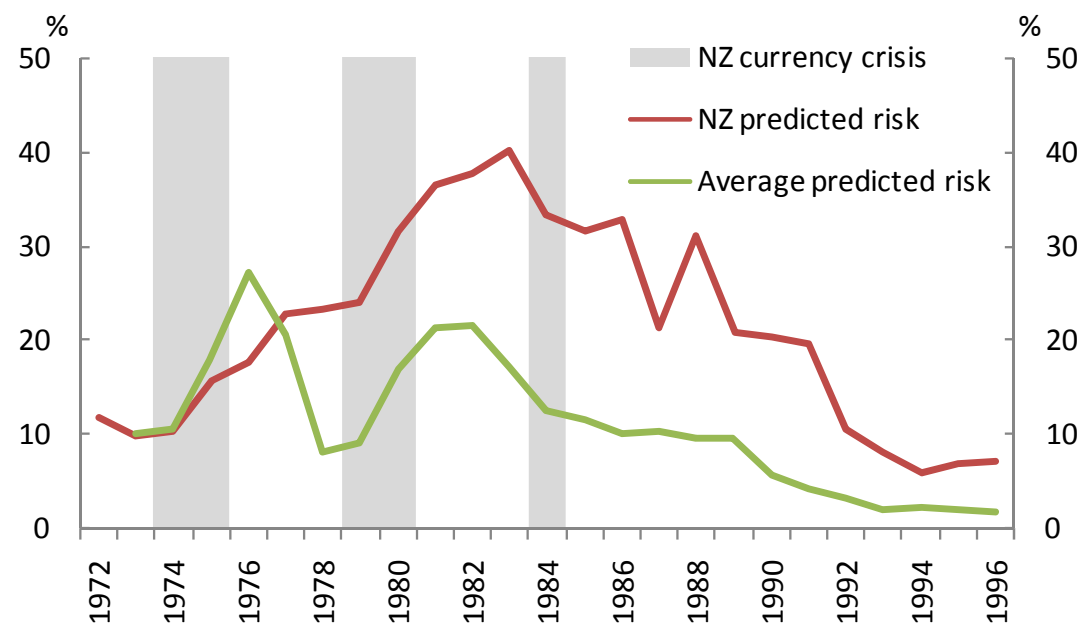

${ }^{7}$ Because of the lack of cross country data, the regression exercises are not repeated for sudden stops for the second era of globalisation. 


\section{Figure 7}

\section{Differences in predicted risk of a currency crisis for New Zealand vis-à-vis the average country (1972-97 averages)}

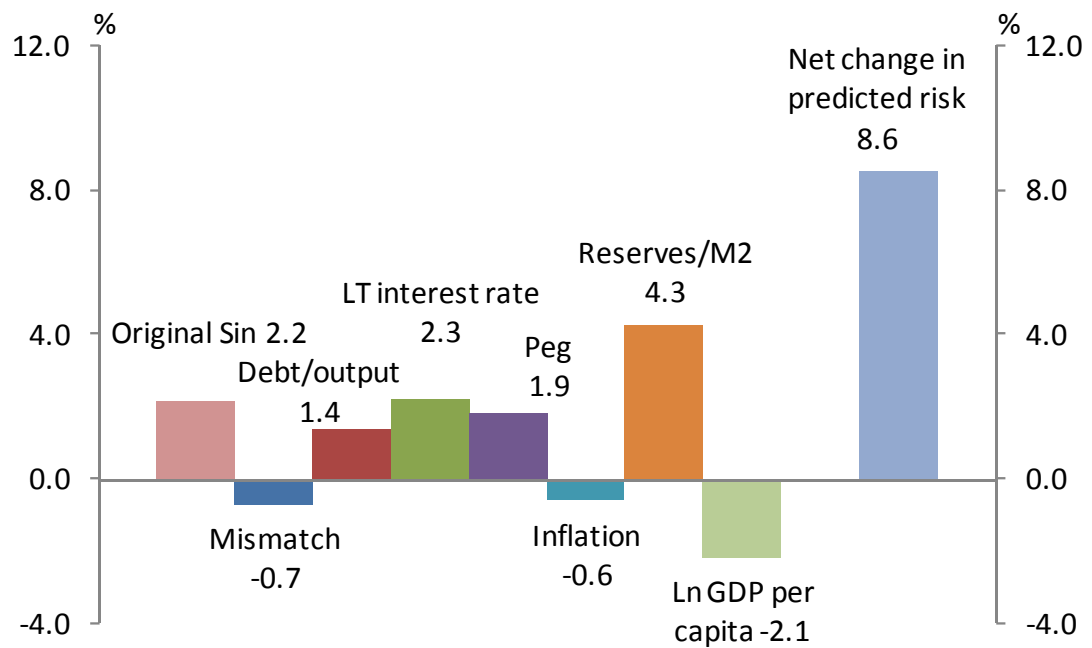

Note: The figure shows the difference in predicted risk of a currency crisis for NZ vis-à-vis the average country in the sample. Each bar represents a marginal contribution of a significant variable in the model (reported in Table 4, column 1) to the difference in predicted probabilities. The marginal contribution of each of the variable is calculated by multiplying the estimated coefficient of the variable to the difference in the average values of the variable for this period between NZ and the average country in the sample. For example, NZ had a higher mismatch than the average country for the period, which the model estimates ( other things being equal) would have added 2.6 percentages point to the predicted risk vis-à-vis the baseline (average country’s) probability.

\subsection{Out-of-sample predictions for New Zealand, 1998-2008}

To understand how risk facing New Zealand has changed since the end of the sample, Figure 8 examines the out-of-sample predictions for New Zealand's probability of currency crises for $1998-2008 .^{8}$ This exercise suggests New Zealand faces much lower risk of a currency crisis today due

\footnotetext{
${ }^{8}$ To produce the out-of-sample predictions, we used the within-sample estimates of marginal effects from the currency crises regression for 1972-1997 (table 4, column (1)), and applied the out-of-sample values for key policy variables in New Zealand (eg mismatch, long term interest rates, etc). The out-of-sample GDP per capita for New Zealand is scaled by the average of the out-of-sample GDP per capita for other countries in the sample to avoid the obvious bias that would result otherwise. Information on out-ofsample GDP per capita for other countries was obtained from the World Bank's WDI database.
} 
to improvements since the mid 1990s in many areas of policy weaknesses identified in the previous period. Declining original sin, mismatch, overall level of debt, long term interest rates and the floating of the NZD are estimated to have had a particularly significant impact in reducing the risk of currency crises based on our cross country model.

It is important to note that declining inflation and long-term interest rates have been features of the last decade for many other countries, and there have been relatively few currency crises. New Zealand risk has declined relative to the average country in the 1972-1997 dataset, but may not have declined as much relative to the average country today. A second important caveat is that new sources of risk of currency crisis have arisen that are not features of our dataset and model. For example, private sector debt has become an increasingly important risk factor for national balance sheets. We believe that cross-country analysis of more recent period exploring new sources of risk for currency crises and sudden stops would be an interesting piece of future work.

In sum, New Zealand was less exposed than the other countries in the sample to the risks of currency crises in the first era of globalisation because of its better fundamentals, but was more exposed to sudden stops because of its relatively high level of original sin. In the second era, New Zealand was more exposed than the other countries in the sample to the risk of currency crises despite its relatively high income per capita (a proxy for 'sound institutions') because of weaknesses in fundamentals such as substantial government debt. Since then, improvements in fundamentals have reduced the risks of currency crises facing New Zealand, according to our model, but it is important to note that new sources of risks that our model does not capture have arisen in the recent international financial crisis. 
Figure 8

Out of sample differences in predicted risk of a currency crisis for New Zealand vis-à-vis the average country (1998-2008)

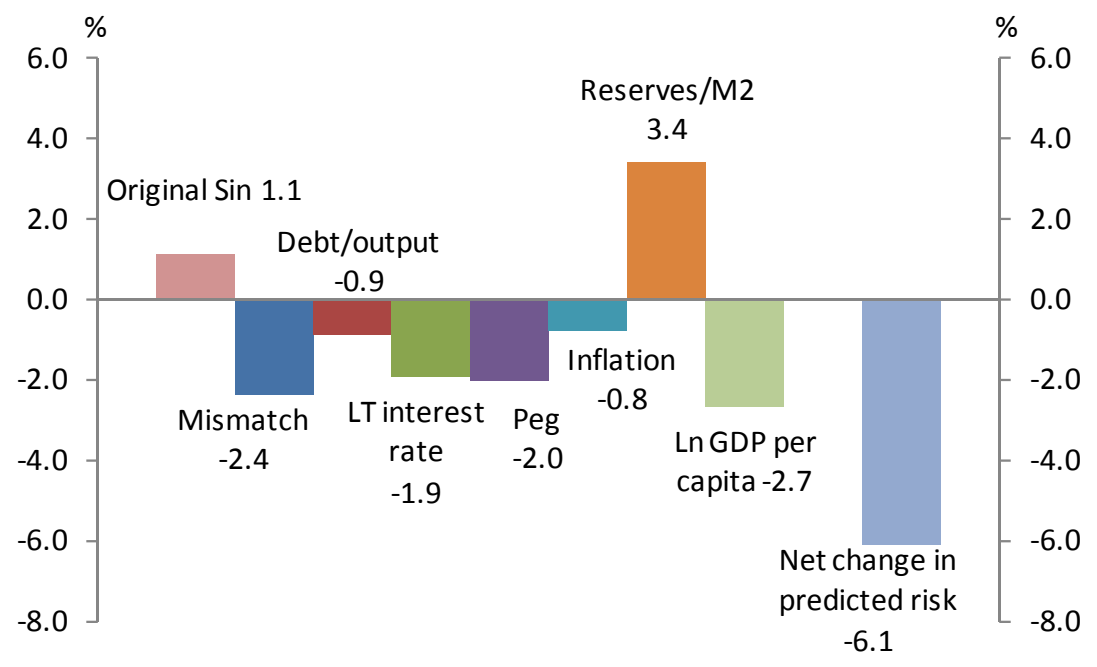

\section{Global shocks, financial crises and the New Zealand economy}

In this section, we explore the impact of financial crises on New Zealand growth and compare it to the impact of global influences such as major country growth or the terms of trade. New Zealand's small size means we can use trading partner growth and world price variables to explain New Zealand growth without worrying about causality issues: if New Zealand macroeconomic variables are correlated with global macroeconomic variables, it must be the global variables driving New Zealand growth rather than the other way around. ${ }^{9}$ Because we are dealing with a 120 year dataset spanning multiple exchange rate regimes and many technological shifts we naturally do not expect the precise lags between variables to have been stable. For this reason, and also to eliminate noise, we use a smoothed growth rate (the three year change in the three year moving average) for the dependent variable (NZ growth) and most of the explanatory variables. We

\footnotetext{
${ }^{9}$ This has frequently been exploited in empirical work (see e.g. Buckle et al 2002) looking at higher frequency data for the post-reform period.
} 
refer to this transformation below as a smoothed growth rate or simply growth.

The global macroeconomic variables we consider are the US growth rate, terms of trade, and UK consol rate. We include the US growth rate as an indicator of global economic activity. We also tried UK growth as well as (or instead of) US growth in unreported specifications, but this did not fit well. While the direct trade links between New Zealand and the UK were more important than New Zealand/US trade until the mid 1970s, the US was already a key driver of the global business cycle in the interwar period, and this may be why US growth fits better (figure 9). As discussed below, we use UK real interest and a UK/NZ real exchange rate in the regression. We use these UK variables partly because of data availability, but also because of the strong direct trade links, and the fact that the UK was the key overseas capital market for New Zealand firms for much of the period under examination. New Zealand's terms of trade is also expected to be an important independent driver of domestic activity (with commodity booms boosting farm incomes for example) and does indeed add a lot of explanatory power to the regression. 


\section{Figure 9}

Real smoothed per-capita growth rates (USA and New Zealand)

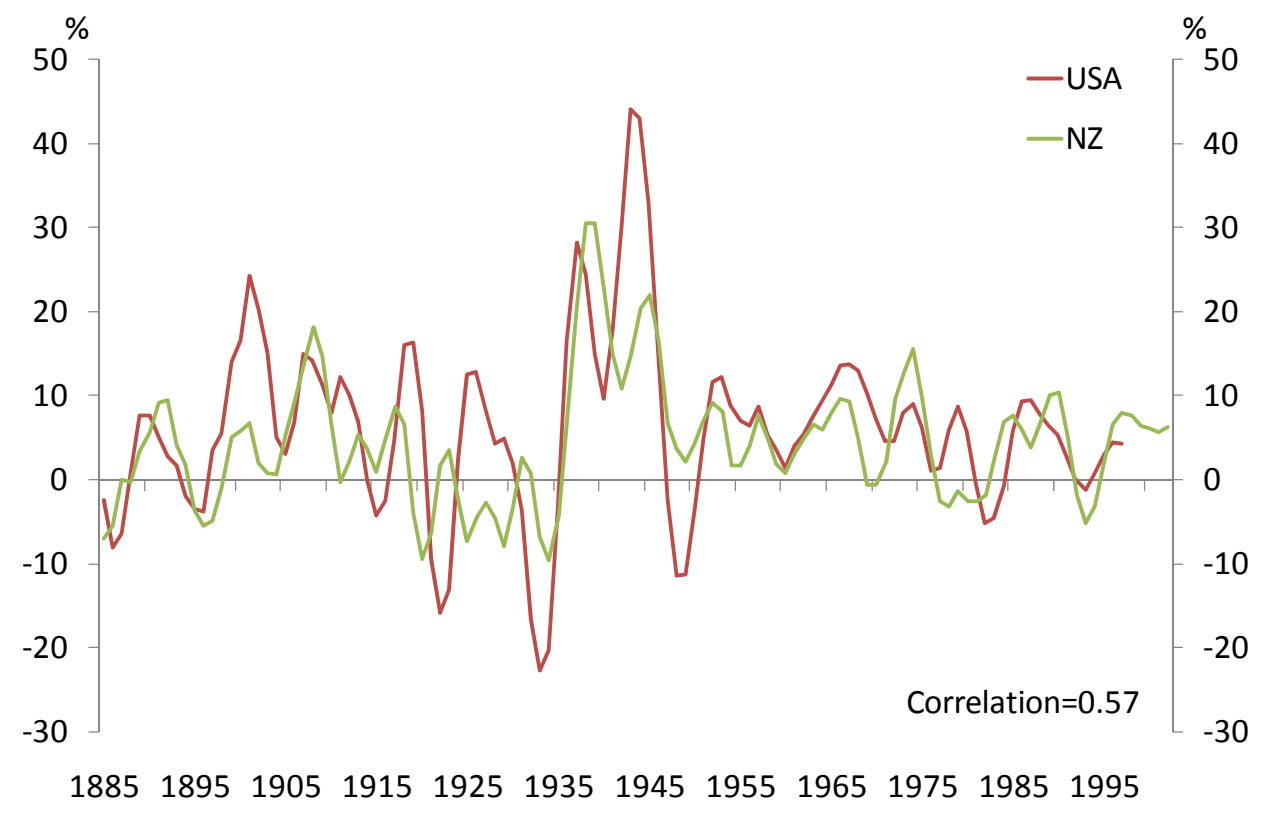

Before adding crisis variables, we experimented with simple regressions of NZ growth on domestic policy variables. We were unable to find a stable relationship between NZ growth and domestic real interest rates over the period. This may reflect the multiplicity of monetary policy regimes, which limits the ability of the simple model to identify monetary policy shocks (eg endogenous monetary tightenings may be coincident with strong economic growth). The relationship between NZ growth and the real exchange rate (of the NZD against sterling) was more stable. The NZD gradually depreciated against sterling until around the 1930s while measured UK inflation generally outpaced NZ's through the period, so that the real exchange rate gradually fell (figure 10). The fluctuations in the smoothed real exchange rate were well correlated with the smoothed terms of trade growth rate (figure 11). 
Figure 10

NZ/UK nominal exchange rate, relative CPIs and implied real exchange rate, 1880-2008

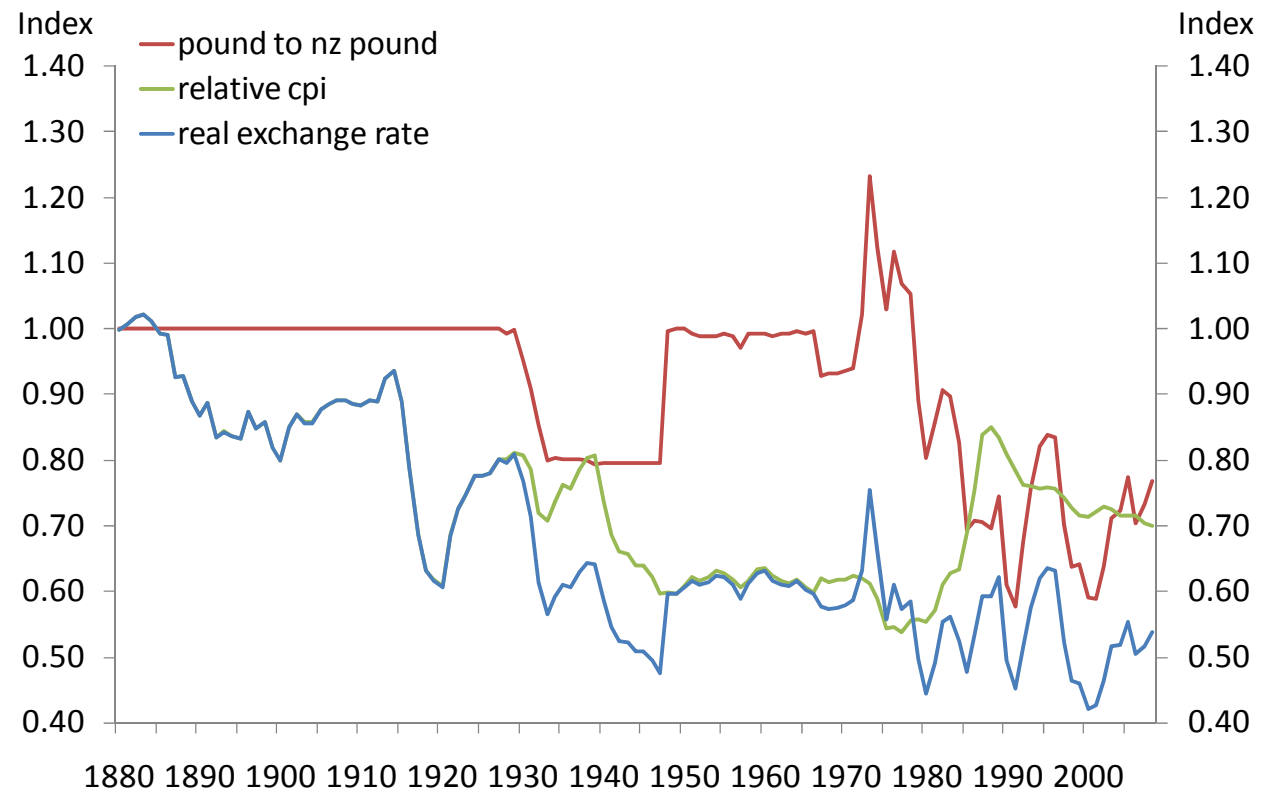




\section{Figure 11}

\section{Fluctuations in the smoothed real exchange rate and the terms of trade}

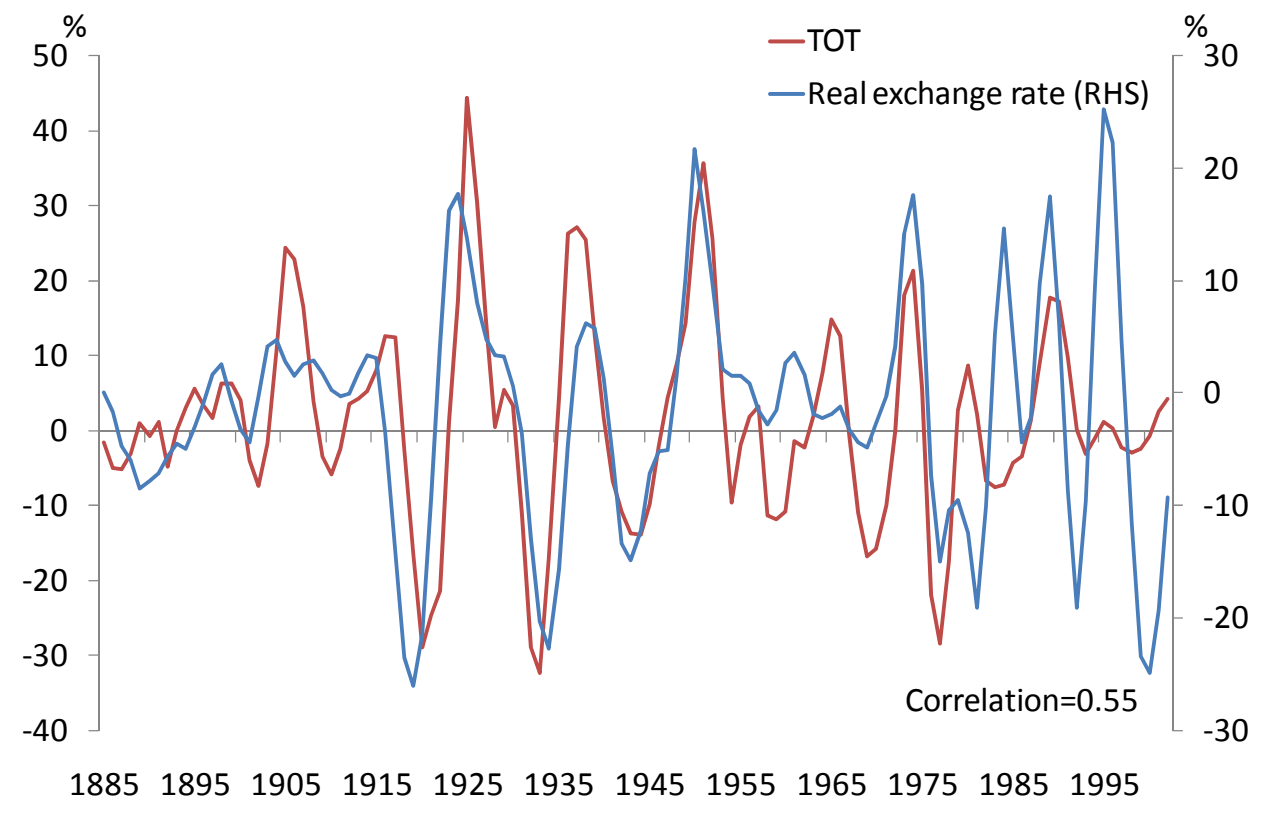

Table 5, column 1 shows our benchmark regression in which NZ growth is explained by the smoothed growth rates of the terms of trade, the real exchange rate and US growth To account for serial correlation in the residuals induced by the three year growth rate we added an AR(2) process for the residuals.

As can be seen, real US output, the terms of trade and the real exchange rate are statistically significant and have expected signs. The UK real interest rate was not significant but is correctly signed. The adjusted R2 of .85 suggests that these variables do reasonably well in explaining New Zealand growth although removing the AR (2) terms reduces the adjusted R2 to close to $50 \%$. 


\section{Table 5}

\section{Regressions explaining fluctuations in New Zealand growth}

\begin{tabular}{lrr}
\hline \hline & $(1)$ & $(2)$ \\
\hline & & \\
Constant & 3.05 & $\mathbf{3 . 2 4}$ \\
Terms of trade (-1) & $(2.62)$ & $(2.75)$ \\
& $\mathbf{0 . 1 7}$ & $\mathbf{0 . 1 6}$ \\
US per capita GDP (-1) & $(3.64)$ & $(3.55)$ \\
& $\mathbf{0 . 1 8}$ & $\mathbf{0 . 1 6}$ \\
Real exchange rate (-3) & $(2.32)$ & $(2.13)$ \\
& $\mathbf{- 0 . 1 4}$ & $\mathbf{- 0 . 1 5}$ \\
Real UK Consol rate (-3) & $(-1.99)$ & $(-2.20)$ \\
& 0.10 & 0.15 \\
NZ Capital inflows (-1) & $(0.51)$ & $(0.76)$ \\
& & $\mathbf{6 . 8 7}$ \\
NZ Bank crisis dummy & & $(2.03)$ \\
& & -1.76 \\
Residual AR(1) term & $\mathbf{1 . 3 1}$ & $(-1.26)$ \\
& $(16.05)$ & $\mathbf{1 . 3 2}$ \\
Residual AR(2) term & $\mathbf{- 0 . 5 9}$ & $-\mathbf{0 . 5 9}$ \\
& $(-7.35)$ & $(-7.22)$ \\
Number of observations & & \\
Adjusted R & & \\
\hline
\end{tabular}

Note: Dependent variable, Terms of trade, US GDP and real exchange rate are smoothed growth rates (the three year change in the three year moving average). Capital inflow is a 2 year change in the 2 year moving average ratio to GDP. T-statistics in parentheses.

Significant coefficients (at 5\% or better) are shown in bold.

We then introduced our different measures of NZ crisis dates into the regression. We tried specifications (not reported) that included the indicators of currency crises or sudden stops from table 1 above, but they were not statistically significant and were often incorrectly signed. This differs from the results in cross-country analysis like Bordo, Cavallo and Meissner (2007) where sudden stops have a discernable impact on growth. This may be because we have a number of variables in the regression (such as the terms of trade and world interest rates) which are likely to be correlated with sudden stops (indeed Bordo, Cavallo and Meissner use them 
as explanators of sudden stops in an earlier regression).

In specification (2), we use a measure of capital inflows ${ }^{10}$ rather than a binary sudden stop indicator, and this is correctly signed and marginally significant. Also in specification (2), the two periods of banking crisis have a negative impact on growth, although the coefficient is not precisely estimated or significant. The coefficient is consistent with a four year banking crisis reducing output by about 2.5 percentage points in total.

Figure 12 illustrates the impact of all the regressors in the benchmark regression (the black line) compared to the actual variable (blue line). The impacts of the key driving variables are represented additively by the stacked bars. To make the influences of the driving variables clearer the autocorrelation in the residuals is not included in the fitted values. US growth and the terms of trade explain much of the variation in real growth across many of the growth cycles. The real exchange rate often partly offsets the terms of trade effect (so the exchange rate is acting as a buffer). Fit is generally good, however the regression struggles to explain the weakness of New Zealand's economic performance in the second half of the 1920 s (a period noted as difficult to explain by other writers). ${ }^{11}$ It is also unable to explain the strength of the economic recovery after the depression, which may partly relate to the imposition of import controls in 1938 and the subsequent shift to wartime production. The banking crisis variable helps explain weak periods of growth around the two banking crises. The impact of the capital flow variable is relatively minor.

\footnotetext{
${ }^{10}$ Capital flows are proxied by the inverse of the trade balance (ie $\mathrm{M}$ minus $\mathrm{X}$ ) plus change in reserves. This ignores invisible components of the current account like investment income, but investment income is unlikely to drive the cycle in capital flows. The variable used in the regression is the two year change in the two year moving average of the capital inflow to output ratio. This is mainly to reduce the impact of year to year noise.

${ }^{11}$ Easton (2007) suggests further analysis of the interwar period and the 1920s in particular is necessary. International currency misalignment and the NZ link to Sterling (which was back on gold at an overvalued exchange rate by 1924) may have played a part. The boom in the US may have been making it difficult to attract capital to New Zealand.
} 
Figure 12 Explanatory variables and New Zealand growth

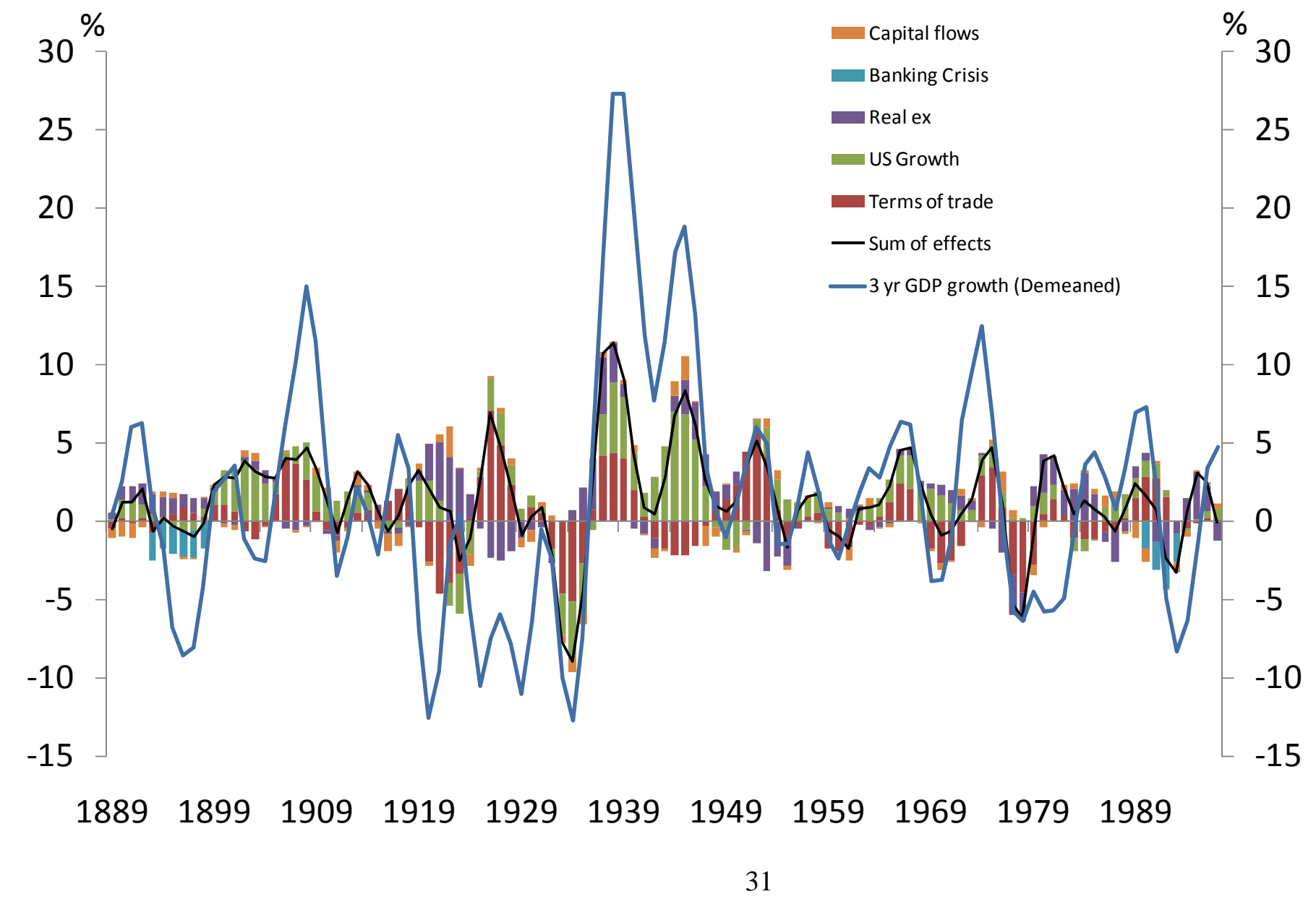


While we preferred to work with smoothed variables for the reasons discussed above, the smoothing can be interpreted as a particular set of parameter restrictions on a simple annual growth regression. To test the robustness of our results to this, we ran some regressions using simple annual growth rates. This naturally did not fit as well (see table A3) but continued to imply the international driving variables (particularly the terms of trade in this specification) explained New Zealand growth better than the crisis variables. This was also true in pre and post WWII sub-samples.

The limited explanatory power of 'crises' over and above international variables is an interesting result. It may reflect the relatively mild nature of many of the 'crises' in New Zealand history (for example, the fact that the two banking crises largely involved a single leading bank rather than the entire banking system and never provoked a widespread collapse in banking confidence). It may also suggest that financial crises in New Zealand are mainly an endogenous response to stress brought on by exogenous global forces rather than a significant independent source of variation in the New Zealand growth rate. It is hard to test this hypothesis for many countries since there is significant two way causality between domestic and international variables, but as discussed above we are able to plausibly treat international variables as exogenous to New Zealand developments.

We next tested whether there was evidence of instability over time in the coefficients of global growth and the terms of trade, using recursive regressions and estimating a simplified version of the benchmark regression with a Kalman filter. The time varying parameters on the terms of trade, US growth and the real exchange rate are shown in figure 13. It appears that the responsiveness of New Zealand growth to these variables may have fallen gradually after 1938 . This could reflect both the extensive economic controls imposed between 1938 and 1984 (the period shaded in blue) and the use of floating exchange rates as an economic buffer post 1984. It is difficult to see much of a difference in the coefficients of the three variables between the 1938-84 period and the subsequent float. 


\section{Figure 13}

\section{Time varying coefficients from New Zealand growth regression estimated with Kalman filter}

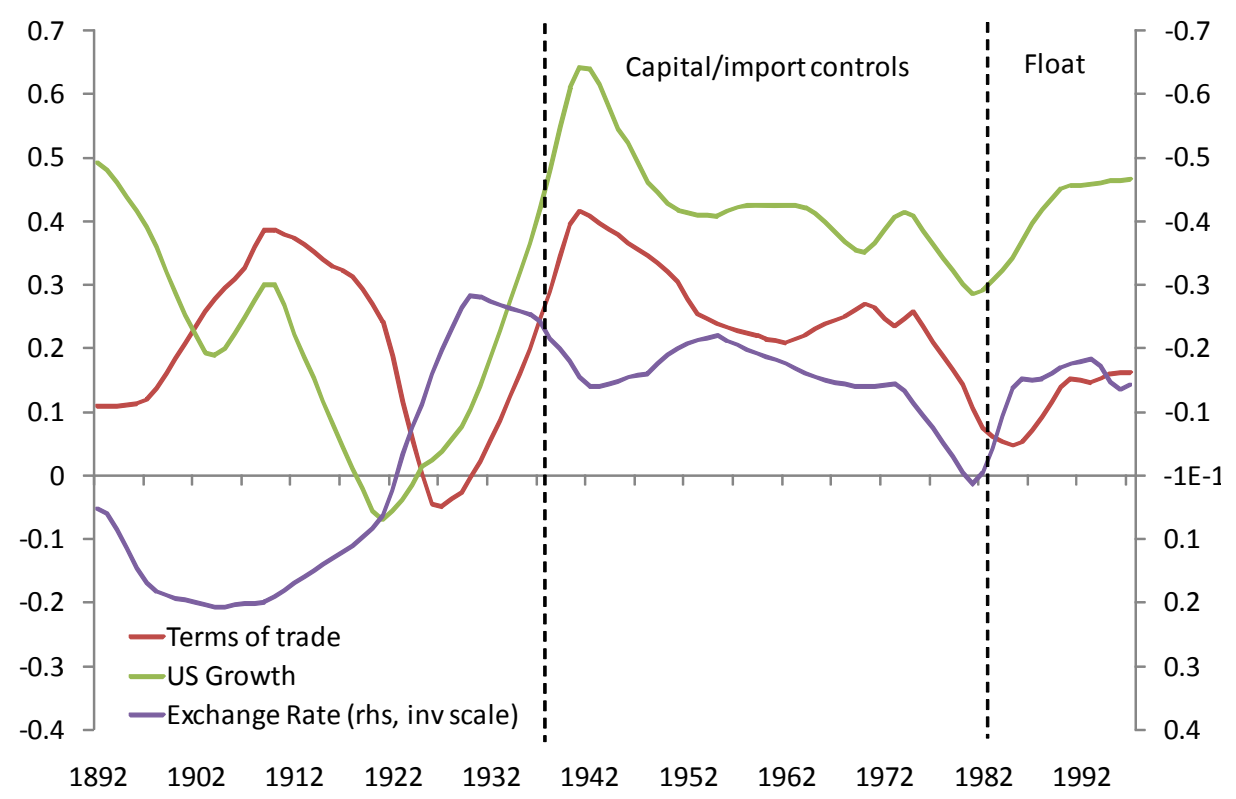

The value of the real exchange rate as a buffer against terms of trade fluctuations is apparent in figure 11. One interesting question is the extent to which the responsiveness of the real exchange rate to the terms of trade may have increased since the 1985 float. A simple regression over 1885-2008 of the smoothed real exchange rate change on the smoothed terms of trade change (with a third lag to allow for the potential for the real exchange rate to respond more slowly in fixed rate regimes) suggests that the real exchange rate responded to the terms of trade in both samples. However, there was less response and some evidence of a lag in the insulationist period (193884) and the full sample, while in the post float period the response was stronger and not lagged. This suggests that the real exchange rate may have buffered terms of trade fluctations somewhat more effectively since the float. 


\section{Table 6}

\section{Regressions of the NZ real exchange rate on the terms of trade}

\begin{tabular}{lrrr}
\hline \hline & $(1)$ & $(2)$ & $(3)$ \\
\hline & & & \\
Constant & -1.82 & -0.72 & -4.46 \\
Terms of trade & $(-2.42)$ & $(-0.49)$ & $(-1.37)$ \\
& $\mathbf{0 . 3 1}$ & $\mathbf{0 . 3 1}$ & $\mathbf{1 . 4 7}$ \\
Terms of trade (-3) & $(4.79)$ & $(3.45)$ & $(2.92)$ \\
& $\mathbf{0 . 1 2}$ & 0.11 & 0.02 \\
Residual AR(1) term & $(1.79)$ & $(1.22)$ & $(0.05)$ \\
& $\mathbf{1 . 3 5}$ & $\mathbf{1 . 2 9}$ & $\mathbf{1 . 3 9}$ \\
Residual AR(2) term & $(23.84)$ & $(9.44)$ & $(12.97)$ \\
& $\mathbf{- 0 . 8 0}$ & $\mathbf{- 0 . 6 6}$ & $\mathbf{- 0 . 8 2}$ \\
& $(-14.03)$ & $(-4.80)$ & $(-7.74)$ \\
Number of observations & & & \\
Adjusted R & & & \\
\hline
\end{tabular}

Note: Real exchange rate and terms of trade are 3 year moving average growth rates. Tstatistics in parentheses. Significant coefficients (at 5\% or better) are shown in bold.

\section{Conclusions and Lessons for Policy}

Financial crises have occurred across most countries and across different exchange rate regimes. Cross country empirical literature studying periods of strong globalisation suggests that countries have some hope of avoiding financial crises by following sound policies and adopting sound institutions, and our analysis of New Zealand appears consistent with this. In the first era of globalisation New Zealand was less exposed to a currency crisis than the average country. For the second era of globalisation, however, New Zealand was more exposed to a currency crisis than the average country because of its weak fundamentals. Our out-of-sample prediction for New Zealand suggests that improvements in many of the policy areas (mismatch, debt to GDP, international reserves, etc.) in the more recent period meant that New Zealand faces much lower risk of a currency crisis today than a decade ago.

However, the global business cycle can still exert powerful effects on small open economies like New Zealand even if they follow basically sound 
policies and avoid serious financial crises. Our time series analyses suggests that shocks to US real GDP (as a proxy for global output) and shocks to the terms of trade have significant impact on New Zealand's medium-term growth. Domestic crisis-dummy variables add little explanatory power to the regressions of its growth rate over and above the impact of the international factors. The relationship between NZ growth and the international factors has remained broadly stable over the 120 year period we study, although we find some evidence that the real exchange rate has been a faster 'shock absorber' in response to terms of trade fluctuations since the float in 1985. 


\section{Appendix}

\section{Appendix A Data Sources}

General notes: Our data for cross country analyses in section four comes from Bordo and Meissner (2006b) and Bordo and Meissner (2009). We appended New Zealand data to their dataset using the Statistics New Zealand (SNZ)'s long-term data series. This includes inflation, government debt and revenue, trade and GDP data, and the terms of trade. To cover more recent years, the long term data series are spliced to modern sources from the Reserve Bank database. Where key variables were missing for NZ we filled them according to the description below.

Reserves: The Bordo and Meissner mismatch measure is (Government external debt - reserves / exports). We do not have data for NZ reserves in the early period (1880-1913)and therefore use estimated values. Specifically, we assumed that NZ maintained the same level of import cover (a ratio of reserves to import) as Australia for the period and multiplied Australia's import cover by NZ's imports to get NZ's reserves. For the most recent period, we use the IFS measure of NZ external debt (line 89a) and of Reserves (line 1l). IFS external debt figures are discontinued around 2001 and we switch to the external debt figures from the SNZ Overseas debt survey.

Exchange rate: The NZD/Sterling real exchange rate is calculated using historical UK CPI data from O'Donaghue (2004) and a nominal exchange rate series from Briggs (2003).

Capital flows: New Zealand capital inflows are estimated using the identity that the current account plus change in reserves is equal to the capital account. The trade balance is used as a proxy for the variability in the current account (debt service being likely to be less cyclical). Reserves data are only available after 1948 (using IFS line 1l) and the change in reserves is assumed to be zero prior to that.

An Exchange Market Pressure indicator is constructed along the lines of Eichengreen, Rose and Wyplosz (1994) to identify currency crises using changes in the exchange rate, interest rates, and reserves. However, the historical use of capital controls and the lack of reserves data prior to 1948 reduce the reliability of this indicator. The currency crises we identify in historical narrative tend to be coincident with actual depreciation in the exchange rate. 
International variables in New Zealand growth regression: International variables in the growth regression are sourced from the Bordo et al (2001) dataset available at michael.bordo.googlepages.com/

\section{Appendix B List of Variables and Definitions}

\begin{tabular}{|c|c|}
\hline Original sin & $\begin{array}{l}\text { Debt that carried a gold clause or made payable at a fixed rate in a } \\
\text { foreign currency as the ratio of this quantity to total public debt } \\
\text { outstanding. Defined as max [0,1-(debt issued in local currency/ total } \\
\text { debt issued by country)] }\end{array}$ \\
\hline Mismatch & $\begin{array}{l}\text { A ratio of the difference between total external debt and international } \\
\text { reserves to exports }\end{array}$ \\
\hline Debt to revenue & A ratio of total debt to total government revenue \\
\hline Growth of terms of trade & Change in terms of trade \\
\hline Trade balance to GDP & Trade balance to GDP \\
\hline Long-term interest rate & Long-term interest rate (\%) \\
\hline UK consol rate & $\begin{array}{l}\text { Interest rate on UK Consol - a form of British government bond, gilt, } \\
\text { dating originally from the 18th century (\%) }\end{array}$ \\
\hline Gold cover ratio & A ratio of international reserves to $\mathrm{M} 1$ \\
\hline Pegged exchange rate & Dummy=1 for country/ year in pegged exchange rates \\
\hline Inflation & Change in CPI when available; otherwise change in GDP deflator (\%) \\
\hline Real GDP per capita (log) & GDP per capita in constant 1989 dollars \\
\hline Banking crises & Dummy=1 for country/ year in banking crisis \\
\hline Hard currency debt to GDP & A ratio of hard currency debt to GDP \\
\hline Growth of money & Changes in M3 \\
\hline Trade openness & A ratio of the sum of exports and imports to GDP \\
\hline Debt to output & Total debt to GNP (\%) \\
\hline $\begin{array}{l}\text { G7 average long-term interest } \\
\text { rate }\end{array}$ & Unweighted average of G7 long-term interest rates (\%) \\
\hline Reserves to M2 & International reserves to $\mathrm{M} 2$ \\
\hline
\end{tabular}


Table A1

Countries in estimation samples

(Number of time-series observations on the right)

\begin{tabular}{|c|c|c|c|}
\hline $\begin{array}{l}\text { Determinants of currency } \\
\text { crises, 1880-1993 }\end{array}$ & Obs. & $\begin{array}{l}\text { Determinants of sudden } \\
\text { stops, 1880-1913 }\end{array}$ & Obs. \\
\hline Argentina & 28 & Argentina & 28 \\
\hline Australia & 32 & Australia & 33 \\
\hline Austria & 32 & Austria & 32 \\
\hline Brazil & 31 & Belgium & 32 \\
\hline Canada & 32 & Brazil & 32 \\
\hline Denmark & 32 & Canada & 32 \\
\hline France & 32 & Denmark & 27 \\
\hline Germany & 32 & Finland & 2 \\
\hline Italy & 32 & Greece & 29 \\
\hline Japan & 7 & Italy & 32 \\
\hline New Zealand & 32 & Japan & 7 \\
\hline Norway & 14 & New Zealand & 32 \\
\hline Portugal & 32 & Norway & 32 \\
\hline Spain & 32 & Portugal & 32 \\
\hline Sweden & 2 & Spain & 32 \\
\hline \multirow[t]{2}{*}{ United States } & 31 & Sweden & 2 \\
\hline & & United States & 32 \\
\hline Total sample & 433 & Total sample & 448 \\
\hline $\begin{array}{l}\text { Determinants of currency } \\
\text { crises, 1972-1997 }\end{array}$ & Obs. & & Obs. \\
\hline Argentina & 9 & New Zealand & 23 \\
\hline Australia & 18 & Norway & 14 \\
\hline Belgium & 18 & Pakistan & 16 \\
\hline Brazil & 13 & Peru & 7 \\
\hline Columbia & 11 & Philippines & 5 \\
\hline Costa Rica & 11 & Sri Lanka & 11 \\
\hline Canada & 17 & Spain & 6 \\
\hline Chile & 13 & Sweden & 19 \\
\hline Denmark & 12 & Thailand & 13 \\
\hline Ecuador & 9 & Turkey & 2 \\
\hline Ghana & 10 & Uruguay & 13 \\
\hline Germany & 5 & United Kingdom & 19 \\
\hline India & 15 & United States & 19 \\
\hline Indonesia & 10 & Venezuela & 10 \\
\hline Jamaica & 12 & Zimbambwe & 9 \\
\hline Malaysia & 13 & & \\
\hline Mexico & 7 & & \\
\hline Total sample & & & 389 \\
\hline
\end{tabular}


Table A2

Frequency of crises by country

(Number of crises in parentheses)

\begin{tabular}{|c|c|c|c|}
\hline $\begin{array}{l}\text { Currency crises, } 1880 \text { - } \\
1993\end{array}$ & Freq. & Sudden stops, 1880-1913 & Freq. \\
\hline Argentina & (3) & Greece & (5) \\
\hline Canada & (3) & Japan & (4) \\
\hline Japan & (3) & New Zealand & (3) \\
\hline Brazil & (2) & Argentina & (2) \\
\hline Germany & (2) & Canada & (2) \\
\hline Italy & (2) & Sweden & (2) \\
\hline France & (1) & Australia & (1) \\
\hline Portugal & (1) & Austria & (1) \\
\hline United States & (1) & Brazil & (1) \\
\hline Australia & (0) & Finland & (1) \\
\hline Austria & (0) & Italy & (1) \\
\hline Denmark & (0) & Norway & (1) \\
\hline New Zealand & (0) & Portugal & (1) \\
\hline Norway & (0) & United States & (1) \\
\hline Spain & (0) & Belgium & $(0)$ \\
\hline \multirow{2}{*}{ Sweden } & (0) & Denmark & $(0)$ \\
\hline & & Spain & $(0)$ \\
\hline $\begin{array}{l}\text { Currency crises, 1972- } \\
1997\end{array}$ & Freq. & & Freq. \\
\hline Argentina & (8) & Belgium & (2) \\
\hline Zimbabwe & (8) & Brazil & (2) \\
\hline Jamaica & (7) & Canada & (2) \\
\hline Mexico & (6) & India & (2) \\
\hline Pakistan & (6) & Malaysia & (2) \\
\hline Peru & (6) & Norway & (2) \\
\hline Uruguay & (6) & Sweden & (2) \\
\hline Indonesia & (5) & United Kingdom & (2) \\
\hline Spain & (5) & Costa Rica & (1) \\
\hline Turkey & (5) & Ghana & (1) \\
\hline Venezuela & (5) & Sri Lanka & (1) \\
\hline Australia & (4) & Thailand & (1) \\
\hline Chile & (4) & United States & (1) \\
\hline Denmark & (4) & Colombia & (0) \\
\hline Ecuador & (4) & Germany & (0) \\
\hline Philippines & (4) & & \\
\hline New Zealand & (3) & & \\
\hline
\end{tabular}


Table A3

Annual New Zealand growth regressions

\begin{tabular}{|c|c|c|c|c|}
\hline & \multicolumn{2}{|c|}{ (1) } & \multicolumn{2}{|c|}{ (2) } \\
\hline & Coefficient & t-statistic & Coefficient & t-statistic \\
\hline Constant & -4.55 & -1.37 & -5.31 & -1.61 \\
\hline NZ Growth (-1) & .09 & .94 & .04 & .39 \\
\hline NZ Growth (-2) & -.27 & -2.86 & -.29 & -3.02 \\
\hline Terms of Trade & .05 & 1.35 & .05 & 1.55 \\
\hline Terms of Trade(-1) & .02 & .65 & .02 & .66 \\
\hline US Per Capita GDP(-1) & .08 & .90 & .05 & .61 \\
\hline US Per Capita GDP(-2) & -.14 & -1.60 & -.13 & -1.54 \\
\hline Real UK Consol rate(-2) & -.36 & -1.34 & -.20 & -.75 \\
\hline Real exchange rate(-2) & -.09 & -1.33 & -.09 & -1.34 \\
\hline NZ Capital inflows & & & 11.68 & 1.23 \\
\hline Banking Crisis indicator (-3) & & & -3.92 & -2.38 \\
\hline Sudden Stop Indicator (-2) & & & .07 & -.75 \\
\hline $\begin{array}{l}\text { Wald test on terms of trade } \\
F(1,100)\end{array}$ & \multicolumn{2}{|c|}{4.77} & \multicolumn{2}{|c|}{6.30} \\
\hline Adj $R^{2}$ & \multicolumn{2}{|c|}{.15} & \multicolumn{2}{|c|}{.18} \\
\hline $\mathrm{N}$ & \multicolumn{2}{|c|}{109} & \multicolumn{2}{|c|}{109} \\
\hline
\end{tabular}

Variables are as discussed in the main text, but NZ and US growth, the real exchange rate and the terms of trade are simple annual growth rates rather than the 3 year change in the 3 year moving average used in the main text. Wald test on terms of trade tests (and rejects) the restriction that the terms of trade coefficients sum to zero. 


\section{References}

Bordo, M, Eichengreen, B, Klingebiel, D and M Soledad Martinez-Peria (2001), 'Is the Crisis Problem Growing More Severe?” Economic Policy 32, 51-75.

Bordo, M, Cavallo, A and C Meissner (2009), "Sudden Stops: Determinants and Output Effects in the First Era of Globalisation” UC Davis (mimeo).

Bordo, M and C Meissner (2006a), "Financial Crises, 1880-1913: The Role of foreign Currency Debt” in S. Edwards, G. Esquivel, G. Marquez (eds) Growth, Protection and Crises; Latin America from an Historical Perspective. Chicago, University of Chicago Press.

Bordo, M and C Meissner (2006b), 'The Role of Foreign Currency Debt in Financial Crises: 1880-1913 vs 1972-1997’ Journal of Banking and Finance. 60, 3299-3329.

Bordo, M and C Meissner (2009), "Foreign Capital and Economic Growth in the First Era of Globalisation” UC Davis (mimeo).

Bordo, M, Meissner, C and D Stuckler (2009) "Foreign Capital, Financial Crises and Economic Growth: A Long-Run Perspective.” UC Davis (mimeo).

Buckle R, Kim, K, Kirkham, H, McLellan, N and J Sharma (2002), "A structural VAR model of the New Zealand business cycle", Treasury Working Paper Series 02/26.

Briggs, P (2003), Looking at the numbers: a view of New Zealand's economic history, Wellington, New Zealand Institute of Economic Research.

Caballero R, Cowan, K and J Kearns (2005), "Fear of Sudden Stops; 
Lessons from Australia and Chile” Journal of Policy Reform 8 (4), 313-354.

Eichengreen, B and R Hausmann (1999), "Exchange Rates and Financial Fragility” in New Challenges for Monetary Policy, Federal Reserve Bank of Kansas City.

Eichengreen, B, Rose, A and C Wyplosz (1994), "Speculative Attacks on Pegged Exchange Rates: An Empirical Exploration with Special Reference to the European Monetary System”, NBER Working Paper 4898.

Hunt, C (2009), "Banking Crises in New Zealand - an historical overview" Reserve Bank of New Zealand conference paper URL www.rbnz.govt.nz/research/workshops/june2009/3732343.pdf

O'Donoghue, J (2004), “Consumer Price Inflation Since 1750”, Office for National Statistics Economic Trends No. 604, 38-46

Quigley, N (1992), "Monetary Policy and the New Zealand Financial System: An Historical Perspective” in Monetary Policy and the New Zealand Financial System (third edition) Wellington, RBNZ, 205-231.

Reddell, M and C Sleeman (2008), "Some perspectives on past recessions” RBNZ Bulletin, 71(2), 5-21.

Reinhart, C and K Rogoff (2008), "Is the 2007 U.S. Subprime Crisis So Different? An International Historical Comparison.” American Economic Review Vol. 98 No. 2, 339-344. 